\title{
Anthropocene Physiography and Morphology of Chilika; India
}

\author{
Siba Prasad Mishra ${ }^{1^{*}}$, Rabindra Nath Nanda ${ }^{2}$, Saswat Mishra ${ }^{3}$ and K. C. Sethi ${ }^{2}$ \\ ${ }^{1}$ Department of Civil Engineering, Centurion University of Technology and Management, BBSR, \\ Odisha, India. \\ ${ }^{2}$ Department of Civil Engineering, Centurion University of Technology and Management, Jatni, BBSR, \\ Odisha, India. \\ ${ }^{3}$ Dept of Civil Engineering, Kalinga Institute of Industrial Technology, KIIT Road, Bhubaneswar, \\ Odisha, India.
}

\section{Authors' contributions}

This work was carried out in collaboration among all authors. Author SPM designed the study, performed the statistical analysis, wrote the protocol and wrote the first draft of the manuscript. Authors RNN and KCS managed the GIS and RS works of the study. Author SM managed the literature searches. All authors read and approved the final manuscript.

Article Information

DOI: 10.9734/ARRB/2021/v36i230344

Editor(s):

(1) Prof. Tunira Bhadauria, Kanpur University, India.

Reviewers:

(1) H. Yıldırım Dalkiliç, Erzincan Binali Yıldırım University, Turkey.

(2) R.Uma Maheswari, Mother Teresa Women's University, India Complete Peer review History: http://www.sdiarticle4.com/review-history/66525

Original Research Article

Received 15 January 2021

Accepted 21 March 2021

Published 26 March 2021

\section{ABSTRACT}

Introduction: Based on stratigraphy, events, ecology and climatology, the present time is assigned Anthropocene epoch due to dominance Homosapiens over geo- bio-hydro-aero spheres of the mother earth during its accepted Anthropocene epoch succeeding the official 11700 years old Holocene epoch from 1950. Asia's largest shallow brackish water lagoon, the Chilika housed over about $1000 \mathrm{~km}^{2}$, behind $64.3 \mathrm{~km}$ barrier spit with multiple tidal inlets to Bay of Bengal. It is sinking and shrinking due to rapid dimensional diminution, environmental degradation, sedimentation, salinity depletion, phytoplankton invasion. Present study envisages the elementary morphology, formation mechanism, sediment transport, and dynamic performance of tidal inlets and the lagoon by applying GIS methodology between the year 1930 and 2017 including its local catchment land use changes within the lagoon and associated south Mahanadi delta. Under vulnerability, the 
brackish water lagoon is constantly deteriorating its ecosystem, it is required for wise use of the wetland that can alleviate the poverty, uplift lagoon users economy, and disallowing the stakeholders living standard during present Anthropocene epoch

Keywords: Anthropocene; Chilika lagoon; Mahanadi delta; morphology.

ABBREVIATIONS

\begin{tabular}{|c|c|}
\hline$S M D$ & South Mahanadi delta; \\
\hline$R S L R$ & : Regional sea level rise; \\
\hline$Y B$ & :Thousand years before presen \\
\hline 19 & $\begin{array}{l}\text { :International Union of } \\
\text { Geological Sciences; }\end{array}$ \\
\hline ICS & $\begin{array}{l}\text { :The International Commission } \\
\text { on Stratigraphy; }\end{array}$ \\
\hline & : tidal inlets \\
\hline
\end{tabular}

\section{INTRODUCTION}

Coastal lagoons are fugacious hydrologic landforms in geological time scale and ephemeral water body sustains for three to four thousand years [1]. The Chilika is formed during three to four thousand years before present (KYBP) estuarine brackish water lagoon which was wellthought-out as a gulf in coastal environment in past. The estuarine amphitheater is attached to the south Mahanadi delta (SMD) of south Odisha that spreads over east coast of India. The Lagoon enjoyed tropical climate, burgeoning demography and was running with wide-ranged fiscal growth in past with port, and harbor activities. Presently the lagoon users are running under marring economy, impairing food and water security. It is also facing numerous meteorological extremes and has problems of sedimentation, diminutions and weed infestation. Severe stress on its biome has led to biodegradation, ecosystem services depletion from 1980 to till date.

The Chilika area was an estuary of the river Daya, low lying coastal areas prior to Holocene epoch [2]. Later regional sea level rise (RSLR) has inundated the area during pre-Holocene. It was transformed to a shallow lagoon after construction of a barrier pit from south. The continuous declining of its expanse had reduced the Greater Chilika (area $1500 \mathrm{Km}^{2}$ ) had shrank and shallowed it to $\approx 1000 \mathrm{Km}^{2}$ as on date. Now it is struggling for its survival as a river/tide induced flushing lacustrine area with asymmetric inland vs. tidal flow. The large water body was having marine connectivity of east and west till $15^{\text {th }}$ century. It is under threats of conversion to a freshwater lake or swamp due to loss of depth, and loss of oceanic-inland exchanges. Records reveal that it started declining under burgeoning demographic growth and anthropogenic pressure has increased from 1970 onwards.

\subsection{Geological Time Scale Stratification}

The geological time scale the earth is running as on date in the Phanerozoic eon, Cenozoic era, Quaternary period and widely accepted Anthropocene epoch though not declared by the International Union of Geological Sciences (IUGS) and the International Commission on Stratigraphy (ICS). The Anthropocene epoch has succeeded the 11.7K years old Holocene epoch after the nuclear explosion on $16^{\text {th }}$ July 1945 (proposed 1950). The dominance of homosapiens over geo-bio-hydro and atmosphere is the Anthropocene epoch [3,4]. The homosapiens evolution was from $\approx 2.0$ MYBP and is mainly accountable for the frame work for the eco-system anomalies, climate changes [5].

\section{REVIEW OF LITERATURE}

The post Holocene research works were scanty and were mainly based on history Sterling et al. [6], Cotton FC. [7], etymology, geography, geology, hydrology, and hydraulics Harrish JC. [8],Blanford [9], Mahalanobish [10], report (unpublished) and geomorphology of the Chilika lagoon and the south Mahanadi delta were studied by various in the past before $16^{\text {th }}$ to $19^{\text {th }}$ century by, Hunter [11], Sewell RBS [12], William et al. [13]. The extensive study of flora, Biswas [14], fauna Stephenson [15], Annadale N [16], Annandale, Kemp [17], Chaudhury BL [18], avifauna and the aqua faunal diversity and availability were studied by many authors during last part of Holocene epoch $[19,20]$.

Anthropocene studies of geomorphology of coastal systems was originated by Pritchard D. W. [21], by defining inland ocean connected systems like lagoons, estuaries, Fjords etc. The studies such as estuaries, O'brien [22], Lagoon, Phleger [23], Fjord, Bay, strait and tidal rivers are 
explained by Kjerfve et al. [24,25]. The origin and sorting of the lagoons are initiated by Lankford R. [26], Fair Bridge [27], worked on classification of lagoons, coastal processes, Kjerfve et al. [24,25]. The tidal inlets formation occur under high energy and constrict the coastline due to asymmetrical sediment transport at the estuaries head or drowned river valleys with growth of spits and barrier islands, Fitz Gerald et al. [28], Mishra SP. [29]. The closing and opening of tidal inlets in the barrier spit of the lagoon take place by wave action, sedimentation and littoral drift Mishra SP. [30]. Anthropogenic and natural factors change geomorphology of a lagoon Mee [31], Mangor K. [32], Nayak PK. [33], Pradhan S et al. [34],

The Chilika lagoon was declared as a Ramsar site number 229 , on 1st Oct., 1981, based on Zoological survey report of India 1985-87, placed in IUCN red list in 1993 for its biodegradation and vulnerability of conversion to a sweet water lake, during the golden spike period of the Anthropocene. Its ecology [35], archeology, meteorology [36], hydrology [37], geomorphology [38], fluvial influx [39], sedimentology $[40,41]$ and lithology and geography [42,43], Sarkar et al. [44] were researched and unanimous opinion was about deteriorating health of the lagoon.

The pre-Anthropocene period from 1950 to 1980; many researchers have worked on the lagoon on various aspects; like its geography, formation of Chilika Venkat ratnam K [45], Change in coast line, flora, fauna Mahapatra LK. [46], avifauna Kachar KS. [47], methods of catching Jhingran VG. [48], geography, hydrology, sedimentology etc., Venkatratnam K [49], Roy Chaudhuri B. [50], Banerjee AC [51]. They have worked in different fields like geology, Bhattacharaya $\mathrm{S}$. [52], Sahu et al. [53], Nandi AK. [54], hydrology Das et al. [55], Das et al. [56], Mukherjee S. [57], meteorology Mishra SP et al. [58], water resources Mishra SP [59], Hazara et al. [60], petrology Mohanty et al. [61], geomorphology Pattanaik S [62], Environmental impact assessment Bhatta et al. [63], sedimentology, radiology, Fossils and pollen grain studies and other fields Mishra SP. [64].

The lagoon started deteriorating gradually from 1980 onwards on the wake of golden spike period of the Anthropocene Epoch. Under the emerging anthropogenic pressure, climate change and meteorological extremes, the lagoon users are put to threat of their livelihood, and the ecosystem since last 3-4 decades. Least researches particularly made over Physiography and morphology of SMD and the associated Basin of the lagoon.

\subsection{The Scope of the Study}

The lagoon Chilika is of estuarine ephemeral in character of catchment area of $4577 \mathrm{~km} 2$. The basin canopy comprises of the western catchment $2800 \mathrm{sqkm}$ and SMD of $1777 \mathrm{sqkm}$ draining locally to Chilika at a ratio constituted $61.15 \%$ and $38.85 \%$ along with supplemented by about $6 \%$ high flood flow of the Mahanadi river through the rivers Daya and the Bhargovi [65]. The lagoon has capacity of $4 \mathrm{Km} 3$ with average inland inflow of 14331 MCUM per year [66]. The local catchment of Chilika consists of denudation hills (southern fringe), sand dunes and barrier spit along coast in the east, swamps of about $4300 \mathrm{~km} 2$ in NW and alluvial deltaic plains of the SMD [67]. The studies were made on zone of littoral transition, the Chilika coastline geology [68], Rao N Kakani et al. [69]. A considerable number of researchers have studied on the geomorphology, coastal activities, socio political issues, physiochemical character in the lagoon to meet the human requirement. Least work is done on Physiography and morphology changes of SMD and the western catchment which is the present scope of the study.

\section{OBJECTIVE}

The study is made to probe the climatic, anthropogenic interventions on the lake dimensions, salinity, ecosystem disparity, and migration due to economic disproportion during both the pre-Anthropocene (1945-1980) and great acceleration period (1981-till date). The changes include the lake characteristics, land use and land cover of the catchment, the pollution rate, salinity changes, inland flow, biodiversity, coastal spit and contentious issues, relate to the flash points for degradation of the panoramic lagoon. During early 21 st century, ameliorative measures are taken considering threats to the Chilika. They are dredging a direct mouth at Sipakuda (2000), operation of Naraj barrage at delta head (2004), renovating Gabakund cut and the channel from Badagotha to the tidal inlets (TI's) in OC. Past researches reveal that all aspects pertinent to the lagoon like soil, water, flora and fauna etc, has been investigated, models are verified on socio economic, political interventions with futuristic 
predictions were made. Least studies are made about the change in geo-morphology of the area as impact of the hydrologic, Anthropogenic and physiographic interventions.

\subsection{Methodology}

The IRS P6 LISS III (1999) and the IRS (Resource-sat 2) and Quick-bird satellite imagery (2013) are downloaded, georeferenced, digitized and layers are provided with the help of ArcMap 10.1 software. The layers are considered for analysis and the thematic picture was obtained for water spread area, vegetative cover, denotation of various types of forest for the years 1987, 2011 and 2016. The steps involved in methodology are in Fig 2.

The survey of India has prepared educational topographical maps in 1:50000 as sheet No $64 \mathrm{P} / 13$ and OSM sheet No F44X13 for Odisha. The Topo sheet numbers 74E $(1,2,3,5,6,9,10$ and 13) were collected and utilized to determine the local catchment area of the Daya and Bhargovi and other rivers basins and drainage channels debouching to the lagoon. The base TEXAS SURVEY map of 1930 of the same scale is collected, georeferenced and compared with the water spread, forest area between the pre and post Anthropocene.

\subsection{South Mahanadi Delta}

The south Mahanadi delta (SMD) extends from emerging place of Kuakhai River at the apex. The Daya and the Bhargovi rivers (distributaries of the Kuakhai), pass through the Bhubaneswar area, and covering 8blocks of Puri district fall in northwest corner of the lagoon (Fig 2).

The major drainage channels are the Ratnachira, the Nuna, the Malaguni, (were in past), the Rajua and the Makara (recent origin). The average flow $(\approx 6 \%)$ to Chilika from the Mahanadi system during flood is about $4 \%$ through the river Daya $(\approx 4 \%$ of total), and the Bhargovi $(\approx 2 \%)$ from 2014. The SMD Rivers contribute in average $61 \%$ of the total inland inflow whereas $70-80 \%$ of the total sediment flows to the lagoon Mishra SP. [78].

\subsection{The Chilika Lagoon}

The Chilika, 2nd largest brackish water lagoon in the globe, (lat. $19.845 \mathrm{ON}$. and long. $85.479 \mathrm{OE}$ ) is a shallow lagoon (Fig 1) separated from Bay of
Bengal (BoB) by barrier spit starting from Palur Hills (Rambha) to Village Motto $(64.3 \mathrm{~km})$. The average water spread area of the lagoon has contracted from $1045 \mathrm{sqkm}$ in early 20 th century to $770 \mathrm{~km} 2$. The coastal stretch was reduced from $71 \mathrm{~km}$ to $64.3 \mathrm{~km}$ during early $21 \mathrm{st}$ century, Ghosh A. [79] and Mishra SP. [80]. The pear shaped wetland has declined its maximum and minimum depth from $4.88 \mathrm{~m}-0.6 \mathrm{~m}$ [81] to $1.42 \mathrm{~m}$ to $0.42 \mathrm{~m}$ in monsoon and summer (1995-1996). The barrier spit is stable for $33.3 \mathrm{~km}$ from south having width $3-15 \mathrm{~km}$ with densely habituated. The balance $31 \mathrm{~km}$ towards north has variable width 0.15 to $1.5 \mathrm{~km}$ is narrow, dynamic and fragile with all inlet dynamics, path for salinity and sediment transport with mangroves, sand dunes, and, few fishermen hamlets.

\subsection{Present Anthropogenic Concerns}

The SMD was urbanized with many townships from 1950 onwards after Bhubaneswar became the capital of Odisha. Many settlements were grown to accommodate the steep rise in population from 1960 along with marginalization of fisher folk and migration from other areas. It is due to growth of different institutions like livelihood, educational, healthcare, tourism and transport etc. The anthropogenic activities on land, water and ecosystem has transformed many swamps and fallow lands to agricultural land or settlements. Making of Mahanadi Delta stage II and barrages in Mahanadi delta system have converted the flood prone area to agricultural bumper zone. To augment the productivity, the ground water was over exploited which resulted in salinity intrusion of inland aquifers. The liquid wastes and effluents from populous areas from urbans and industries have contaminated the coastal aquifers, drains and the river runoff. The water of the Kuakhai River is turned off as unfit for human use during summer months.

About $50 \%$ of the total areas were under cultivation with subsidiary livelihood as fishery, coconut farming in the Chilika and its local Mahanadi basin reported by SREP (ATMA) of Puri District, 2007-08. The sectors like tourism, Industries, township with improved connectivity and irrigation have curbed the life of the rain fed and water logged agricultural workers. They have also engaged themselves their livelihood activities in developing profitable agriproducts, and small scale industrial activities instead of orthodox farming or fishing. 


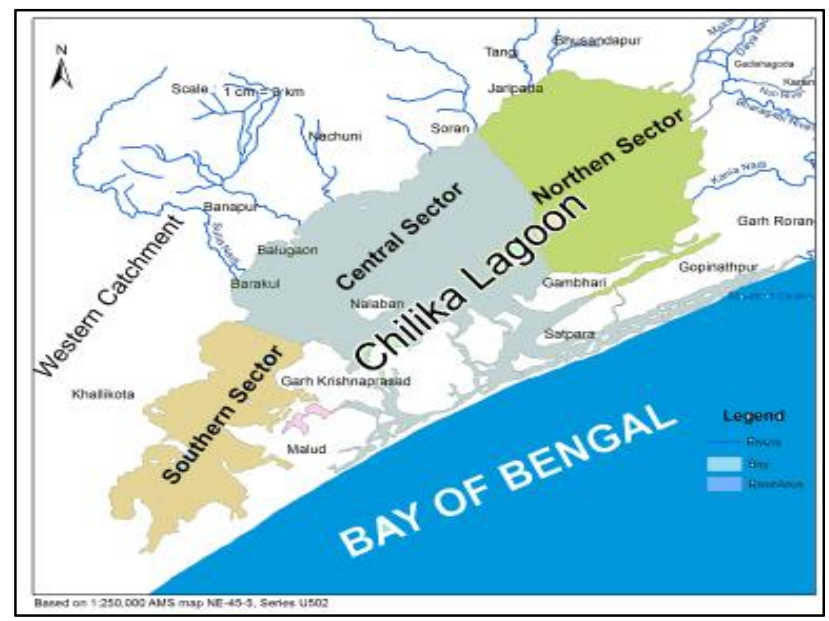

Fig. 1. Index map of Chilika during anthropocene

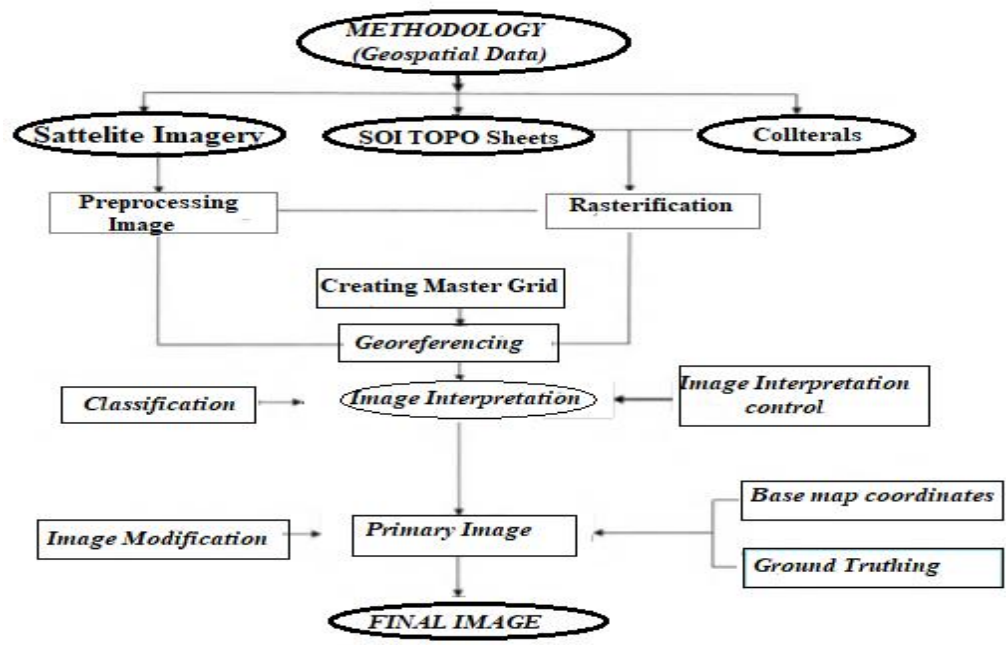

Fig. 2. The methodology of analysis of image by GIS

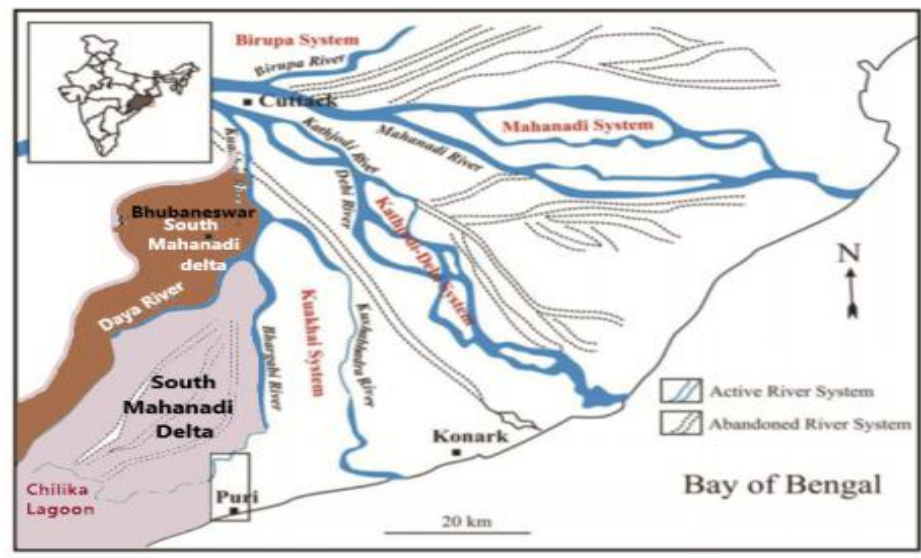

Fig. 3. The SMD in the Mahanadi delta and the Chilika lagoon 


\subsubsection{Deterioration of Chilika (pre and post intervention)}

The lagoon had a deteriorating health from 1990 onwards where a comparative study is given in Table 1.

The lacustrine area of the Chilika was during 1985 and 1995 were $620 \mathrm{~km} 2$ and $650 \mathrm{~km} 2$ during summer and $700 \mathrm{~km} 2$ and $750 \mathrm{~km} 2$ in post monsoon respectively [74]. But researchers have less attention about the local catchment and meteorological impacts along with anthropogenic pressure over the lagoon. It is felt imperative to study the climatic changes, human interventions and geomorphology changes over the lagoon. The combined anthropogenic interventions have augmented the catch statistics from 1274MT (19995-96) to 16358MT during the year 2017-18, wetland avifauna were about 1142000 (surveyed on 5th Jan 2021, PTI | January 16, 2021) and the number flag ship species like Irrawaddy Dolphins in the year 2020 were 156.

\subsection{Shoreline and RSLR Changes Along Chilika Coast}

Morph-dynamic studies of the micro-tidal Chilika reveals that there was progradation of $0.58 \mathrm{~m}$ between the years 1930 to 1975 whereas retrogradation during 1933 to 2002 was $143.68 m$ The shore line was retreated by $97.18 \mathrm{~m}$ during 2006 (may be due effect of Tsunami 2004) and had increased to $320.754 \mathrm{~m}$, by 2010 where the base year is 1933 [82]. The regional sea level rise along and off Chilika coast is raising @ a rate of $\approx 1.0-1.75 \mathrm{~mm} / \mathrm{annum}$ due as a result of global warming during 21st century, [83]. The present coast line has been separated to southern stable and northern unstable coast.

\subsection{Climate of Study Area}

The climate particularly rainfall of the study area is influenced by both SW and NE monsoon due to variable placing of the ITCZ. The land falling of the BoB cyclones have increased for the last 20years. From 1951 to 2020 the South Odisha coast slammed 17numbers of cyclonic storms between Gopalpur and Konark. Severe cyclonic storms like Fani, Titili, Hudhud, and Phailin were the worst in intensity including 4consecutive storms during 1968. The five severe cyclonic storms had slammed Chilika and SMD coast after 1999 were very severe. The anthropogenic interventions with these natural hazards have made the health of the lagoon wretched. The rainfall in the catchment area has also reduced by $6-7 \%$ (Table 2 ).

\subsection{Drainage flow to SMD}

The river Mahanadi is bifurcated at delta head near village Naraj. At the junction, there is major shift of the flow either to left or right depending on configurational changes after each high flood above 40000 cumec in the main river. Very high floods after the 1950 were during 1982 and 2008. The peak flow bifurcation in branches the Mahanadi and the Kathajodi observed changes (Table 2). The flow through the sub branch Kuakhai, a $2^{\text {nd }}$ order distributary of Kathajodi has reduced peak flow from 2009 onwards reducing Chilika's flushing flow (Table 3).

\section{CHILIKA AND SMD FROM PRE ANTHROPOCENE}

The dimensions of the lagoon recorded to be $1165 \mathrm{Km} 2$ during high floods and $906 \mathrm{Km} 2$ during summer with $71 \mathrm{~km}$ coastal length with maximum width of $30 \mathrm{Km}$ [6]. The present SMD claimed to be made during mid Holocene period (4200YB.P) after renovation of Regional MSL rise by 7 to $8 \mathrm{~m}$ higher than present coast [84] and prograde @ $\approx 9.1 \mathrm{~km} / 000$ ' years [85].

\subsection{The Forest Cover}

The Canopy of the basin was encompassed by $1340 \mathrm{Km} 2$ of forest area. In 1930, the total area was of $\approx 5240 \mathrm{~km} 2$. During 1972 it was reduced drastically to $\approx 856 \mathrm{~km} 2$ and further reduced to $610.39 \mathrm{~km} 2$ during 1989. An active step for restoration of the deteriorated forest, the rate of jungle loss was reduced $\approx 572.81 \mathrm{Km} 2$ in 2004 . By massive afforestation and public participation in forest management, the rate of loss had further reduced to $568.14 \mathrm{Km} 2$ [75]. The dense forest has increased by $2.2 \%$ between 1989 and 2004 and was converted to open forest and later by 2011 , whereas the dense forest was reduced by $9.48 \%$, Fig 4(A) and Fig 4(B).

The loss of forests was in Chandaka, Patia, Badamal,Tamna, Katuala, Bankar, Dhanai Baharmal, Rajin hills. They were bald in the SMD. Reserve forests which were dense before 1950 were converted to open or shrub forests. The west coast forests affected were in Bhaleri, Jhinkaridi, Solari, Karakhol, Talakhol, Rambha and Ghantashila etc. The mangroves and forests deforested. within the lagoon were in Barakuda and Samala Islands and the spit area. 
Table 1. The deterioration of the Chilika pre intervention period during 1990's of Anthropocene

\begin{tabular}{|c|c|c|c|c|c|c|c|}
\hline \multirow{3}{*}{$\begin{array}{l}\text { The feature object } \\
\text { Pre intervention period }\end{array}$} & \multirow{2}{*}{\multicolumn{2}{|c|}{ Early Anthropocene }} & \multirow{2}{*}{\multicolumn{2}{|c|}{$\begin{array}{l}\text { Fag end of 1990's } \\
\text { Deterioration period }\end{array}$}} & \multirow{2}{*}{\multicolumn{2}{|c|}{$\begin{array}{l}\text { During 2020's } \\
\text { Post intervention }\end{array}$}} & \multirow[t]{2}{*}{ Sources } \\
\hline & & & & & & & \\
\hline & Year & Quantity & Year & Quantity & Year & Quantity & \\
\hline Water Spread Area (Minimum) & 1972 & $824 \mathrm{Km}^{2}$ & 2000 & $790 \mathrm{Km}^{2}$ & 2008 & $704 \mathrm{Km}^{2}$ & ORSAC Data; Gupta et al. [70] \\
\hline Maximum depth & $1985-87$ & $2900 \mathrm{mmm}$ & $1996-97$ & $1420 \mathrm{~mm}$ & 2018 & $4.1 \mathrm{~m}$ & Ghosh [71]; (ORSAC-1997) \\
\hline Minimum depth & $1985-87$ & $400 \mathrm{~mm}$ & $1996-97$ & $420 \mathrm{~mm}$ & 2018 & $1.1 \mathrm{~m}$ & Mukherjee M. [72] \\
\hline Maximum salinity & $1957-58$ & 22.3ppt & 1990 & 15.83ppt & Jun-17 & $\approx 38.7 \mathrm{ppt}$ & Raman et al. [73], \\
\hline Weed spread Area & 1973 & $20 \mathrm{Km}^{2}$ & 2000 & $523 \mathrm{Km}^{2}$ & 2011 & $300 \mathrm{~km}^{2}$ & CDA.Rep. [74] \\
\hline Av mid Ch. Salinity & $1957-58$ & 22.3ppt & 1995 & 1.4-6.3ppt & 20015 & 9.77ppt & CDA Report [74] \\
\hline Aqua Catch & $1985-86$ & 8.667TMT & $1995-96$ & 1.274TMT & 2017 & 12.2MMT & Odisha Fish. Dept. \\
\hline Catch. Forest cover & 1972 & 856Sqkm & 1989 & 610.69 & 2011 & $568.4 \mathrm{~km}^{2}$ & I. Sk Majharul [75] \\
\hline
\end{tabular}

Source: Raman et al. [73], Biswas [76]; Ghosh et al. [71]; CDA Report 2010-11 \& 2012[74], Bulletin 80-CIFRI-1998[77]) 


\subsection{Anthropogenic Interventions (Hydrau- lic)}

The water spread area of the lagoon during Dec 1930 was found to be $877.37 \mathrm{Km} 2$ during summer. Hirakud dam (1956) was the first intervention designed to save Chilika. The continued deterioration of the lagoon afterwards forced for an official opening of $\mathrm{TI}$ at Sipakuda village (2000) and construction of Naraj barrage at head of Mahanadi delta (2004). Two small barrages over river Bhargovi at Gobardhanpur (1998) and submerged weir at Gabakund (2014) were constructed to save the local people from annual flood devastations. The Palur canal leading to the Rushikulya River was renovated. After the hard interventions, the ecosystem has improved from average 8.0MMT to average 12MMT of aqua catches, upsurge in salinity and reduction in proliferation of weeds as rejuvenation of the ecosystem.

\subsection{The Watersheds around the Chilika}

Inland fresh water contribution to the lagoon is through 52numbers of rivers, rivulets and major drainage channels (d/c's). The seven drainage channels of SMD debouch in the northern sector. The serpentine 45 number $\mathrm{d} / \mathrm{c}$ 's emerging from eastern Ghats are debouching the lagoon through western banks Fig 5(a) and Fig 5(b).

\subsection{The Local Catchment of Chilika}

The SMD catchment includes 7rivers/rivulets and the western catchment have 45 drainage channels (D/C's) feeding their flow to the Lagoon. A doab is the upland between two rivers as hydraulic boundary. The local catchment of the Chilika wet land enclosed within of four doabs i.e Doab VII (the Daya-Bhargovi), Doab VIII (West of Daya - the Malaguni), Doab XV (west of Daya - the Salia ), and Doab XVI (the Salia - the Rushikulya) (Fig. 2B) that have canal systems and agricultural lands (Fig 3(a)) and Fig. 3(b). With sea level fluctuations two parallel outer channels exists in the northern fringe of the lake representing strand lines within a distance of 2-3km. (Table 4).

Thus Chilika has three subsystems: Subsystem I is Own catchment of $1560 \mathrm{Km}^{2}$, Subsystem II is flow from SMD Catchment of $1777 \mathrm{Km}^{2}$ ), and Subsystem III the rivers emerging from EGB Hills debouching Chilika as western catchment of area $2800 \mathrm{Km}^{2}$ )

\subsection{Morphological Changes}

The barrier spit is backed by an outer channel of $32 \mathrm{~km}$ long $1-3 \mathrm{~km}$ wide outer channel (OC) of marine environment connected at Magarmunha the doorway of the lagoon. The Hydrodynamics and the salinity and the semi-marine ecosystem of the lagoon is governed by the continuous process of breaking and making of flood-deltas and ebb-deltas in OC. The swash zone controls the flow exchange, northerly shift, and opening/closing of tidal inlets (TI).

The unstable spit configurations oscillate between Hathikhal George to village MOTTO of length $34 \mathrm{Km}$ during the start of Epoch. Tidal action and flow energy of waves are conducive for TI migrations. Dimensions of inlet, islet erosion and accretion, barrier island breaching, sediment imbalance, meteorological extremes, and littoral drift are the causes of mechanics of sediment transport. Sediment bypassing occurs due to wave dynamics near the flood/ebb delta complex, tidal influence and migration of islet complex within the channel [86].

\subsection{The Geomorphology of the Chilika during Anthropocene}

The Chilika maintained its sustainability with difficulties during pre-Anthropocene period (1950 - 1970). Later with sudden population growth and the expansion of Bhubaneswar city, changes in agrarian practices, water use, waste management system, urban growth, changes in LU/LC, mining, and ground water overexploitation and other anthropogenic stresses has altered the geo-bio-hydro climate of the study area. The soil erosion and the balanced sediment deposited in Chilika (after influx and outflow) is about $365.0^{\text {Th }} \mathrm{MT}$ /year Finlayson et al. [87].The Chilika was an estuary of the river Daya in the pre Holocene acting as port till 14 to $15^{\text {th }}$ century connecting the East and the west. The lagoon was inundating up to Kanas area $20 \mathrm{Km}$ $\mathrm{U} / \mathrm{S}$ of the present lake periphery. Later it dried up and suffering for her existence as a brackish water lagoon (Fig. 6).

\subsection{The LU and LC Changes}

Nature has also waned the ecosystem both intrinsic and extrinsically through historic floods during 1982 and 2008 in the Mahanadi system, number of devastating cyclonic storms and erratic monsoon rains and devastator floods in the catchment area of the lagoon. A comparative study of the demographic, habitat and LU/LC 
changes in the lagoon area and the local catchment is compared between Year 1987 and 2016 Fig 7.

The drainage basin of Chilika includes $2325 \mathrm{~km}^{2}$ of agricultural land (mostly dry land), $526 \mathrm{~km} 2$ of forests, $192 \mathrm{~km} 2$ of permanent vegetation predominantly used for plantations, $71 \mathrm{~km} 2$ of swamps and wetlands, and $91 \mathrm{~km} 2$ of grassy mud flats in the northeast of the drainage basin. Only $52 \mathrm{~km}^{2}$ of the basin are occupied by human settlements, roads, railways, and others Ramesh et al. [88], Ghosh et al. [89], Weed spread area [76]; CDA Report 2010-11[74]).

\section{MORPHOLOGICAL FEATURES DUR- ING ANTHROPOCENE}

\section{Off-shore Landforms}

The Chilika coast is the conjoint place of $85^{\circ}$ Ridge and the northern end of the EGB Hills. So the offshore precinct is of shallow zone. The coastal topography along the coastline is influenced by wind, wave, tide, littoral drift, from sea ward. The land ward forces are water and inland silt transport which deforms the coast and coastal landform and vegetation regularly. The main geological landforms that transforms are:

\subsection{Barrier Islands and the spit}

The transversely formed barrier islands or bars in the swash zone are adjacent to coast has developed the beach and always fragile based on the actions of wind, waves, tides, and sediment supply. After formation, growth, and attaining stability (whether submerged or emerged), these bars resist the wave action from both the lagoon and sea side of the Chilika. They are constructed due to deposition of sediments from inland or through longshore drifts under low gradient in front of the TIs [91]. Such bars are found along the mouths of past tidal inlets to the Bay of Bengal coast line from Parikud (southern end of the Chilika) to the southern end of SMD. The spits are curved towards the land at their extreme end like hooks.

The northerly longshore drift of sediment across the Chilika coast, there is accretions and depositions across the shoreline when reaches a bay or form a bend along the seaward shore front. In case of Chilika the main spit is attached to lands of Palur hills near Rambha. The spit had extended up to the Harachandi Temple $(71 \mathrm{~km})$ up to mouth the defunct Sunamunhi $R$. with shrinkage of the lagoon it is presently $64 \mathrm{~km}$ and of width 0.15 to $2 \mathrm{~km}$ [92].

Table 2. Major Av. rainfall in mm of seven block headquarters in SMD and Chilika (2000-2016)

\begin{tabular}{|c|c|c|c|c|c|c|c|c|}
\hline \multirow[t]{2}{*}{ Year } & \multicolumn{5}{|c|}{ DOBA VII (Water Shed -2) } & \multirow[b]{2}{*}{ Kanas } & \multirow{2}{*}{\multicolumn{2}{|c|}{ K Prasad }} \\
\hline & Barang & BBSR & Jatani & Delang & B-giri & & & \\
\hline 2000 & 1572 & 1136 & 1064 & 977 & 483 & 1003 & 750 & 1590 \\
\hline 2001 & 1861 & 1929 & 1439 & 1812 & 1737 & 1761 & 1883 & 2521 \\
\hline 2002 & 1884 & 2005 & 1462 & 1977 & 1766 & 1835 & 1939 & 2629 \\
\hline 2003 & 2785 & 1718 & 1367 & 1189 & 1657 & 1302 & 1443 & 1997 \\
\hline 2004 & 1169 & 1330 & 872 & 1062 & 1117 & 664 & 1130 & 1318 \\
\hline 2005 & 1264 & 1302 & 730 & 1712 & 1078 & 506 & 1220 & 1438 \\
\hline 2006 & 1777 & 1843 & 1449 & 1964 & 1770 & 1830 & 1932 & 2636 \\
\hline 2007 & 1662 & 1551 & 646 & 1412 & 1229 & 1336 & 1388 & 1437 \\
\hline 2008 & 1498 & 1929 & 398 & 1504 & 1497 & 1157 & 1534 & 1884 \\
\hline 2009 & 1183 & 1084 & 546 & 1596 & 1329 & 1962 & 1445 & 1437 \\
\hline 2010 & 1434 & 1469 & 544 & 1668 & 1322 & 1971 & 1378 & 1458 \\
\hline 2011 & 1437 & 1469 & 890 & 1616 & 1287 & 1881 & 1432 & 1408 \\
\hline 2012 & 1377 & 1694 & 1800 & 759 & 1163 & 1243 & 1346 & 1239 \\
\hline 2013 & 1598 & 1846 & 1942 & 945 & 1726 & 1769 & 1695 & 1756 \\
\hline 2014 & 1638 & 1424 & 1839 & 1238 & 1458 & 1737 & 1542 & 1705 \\
\hline 2015 & 969 & 1151 & 1287 & 852 & 812 & 1009 & 1382 & 1279 \\
\hline 2016 & 1569 & 1555 & 1142 & 1393 & 1339 & 1435 & 1465 & 1733 \\
\hline av. & & 1539 & & & & 1418 & & \\
\hline
\end{tabular}

Ref: https://rainfall.nic.in/PubRainChart.asp 
Table 3. The annual peak flow bifurcation at Naraj between main distributaries the Mahanadi and the Kathajodi Br

\begin{tabular}{|c|c|c|c|c|c|c|c|c|c|c|c|c|c|}
\hline Year & $\begin{array}{l}\text { Peak M-nadi } \\
\text { flow }\end{array}$ & Flow & $\begin{array}{l}\text { Max } \\
\text { Kathjodi }\end{array}$ & flow & $\begin{array}{l}\text { Max M-nadi } \\
\text { Br. }\end{array}$ & flow & Year & $\begin{array}{l}\text { Peak M-nadi } \\
\text { flow }\end{array}$ & $\begin{array}{l}\text { \% of } \\
\text { Flow }\end{array}$ & $\begin{array}{l}\text { Max } \\
\text { Kathjodi }\end{array}$ & Flow & $\begin{array}{l}\text { Max Maha } \\
\text { Br. }\end{array}$ & flow \\
\hline & Cumec & $\%$ & Cumec & $\%$ & Cumec & $\%$ & & Cumec & $\%$ & Cumec & $\%$ & Cumec & $\%$ \\
\hline 1964 & 19962 & 100 & 8883 & 44 & 11079 & 56 & 1998 & 22907 & 100 & 17362 & 76 & 5545 & 24 \\
\hline 1965 & 8869 & 100 & 5609 & 63 & 3260 & 37 & 1999 & 17972 & 100 & 9176 & 51 & 8796 & 49 \\
\hline 1966 & 16572 & 100 & 7943 & 48 & 8629 & 52 & 2000 & 5050 & 100 & 3190 & 63 & 1860 & 37 \\
\hline 1967 & 22155 & 100 & 8693 & 39 & 13462 & 61 & 2001 & 39887 & 100 & 20918 & 52 & 18969 & 48 \\
\hline 1968 & 21355 & 100 & 9565 & 45 & 11790 & 55 & 2002 & 16332 & 100 & 11852 & 73 & 4480 & 27 \\
\hline 1969 & 27680 & 100 & 12771 & 46 & 14909 & 54 & 2003 & 38223 & 100 & 11778 & 31 & 26445 & 69 \\
\hline 1970 & 23361 & 100 & 11223 & 48 & 12138 & 52 & 2004 & 21695 & 100 & 11179 & 52 & 10517 & 48 \\
\hline 1971 & 21239 & 100 & 9984 & 47 & 11255 & 53 & 2005 & 25578 & 100 & 13726 & 54 & 11853 & 46 \\
\hline 1972 & 20222 & 100 & 9004 & 45 & 11218 & 55 & 2006 & 36318 & 100 & 17178 & 47 & 19140 & 53 \\
\hline 1973 & 26261 & 100 & 11334 & 43 & 14927 & 57 & 2007 & 20530 & 100 & 10570 & 51 & 9960 & 49 \\
\hline 1974 & 21590 & 100 & 9692 & 45 & 11898 & 55 & 2008 & 44777 & 100 & 24488 & 55 & 20289 & 45 \\
\hline 1975 & 23159 & 100 & 11092 & 48 & 12067 & 52 & \multicolumn{3}{|c|}{ Av. Distn. in M-nadi distribut. 1983-2008 } & 12036 & 52 & 11825 & 48 \\
\hline 1976 & 26438 & 100 & 9518 & 36 & 16920 & 64 & 2009 & 24508 & 100 & 11829 & 48 & 12678 & 52 \\
\hline 1977 & 26475 & 100 & 13995 & 53 & 12480 & 47 & 2010 & 19539 & 100 & 10103 & 52 & 9436 & 48 \\
\hline 1978 & 27881 & 100 & 11700 & 42 & 16181 & 58 & 2011 & 38700 & 100 & 20857 & 54 & 17843 & 46 \\
\hline 1979 & 17727 & 100 & 9856 & 56 & 7871 & 44 & 2012 & 19142 & 100 & 8334 & 44 & 10808 & 56 \\
\hline 1980 & 34747 & 100 & 16481 & 47 & 18266 & 53 & 2013 & 20331 & 100 & 7250 & 36 & 13081 & 64 \\
\hline 1981 & 17535 & 100 & 8085 & 46 & 9450 & 54 & 2014 & 32517 & 100 & 14744 & 45 & 17773 & 55 \\
\hline 1982 & 44750 & 100 & 18716 & 42 & 26034 & 58 & \multicolumn{3}{|c|}{ Av. Distn. in M-nadi distribut. 2009-2014 } & 12186 & 46 & 13603 & 54 \\
\hline$A v . D i$ & M-nadi distribu & 1964-1982 & 10744 & 46 & 12833 & 54 & \multicolumn{3}{|c|}{ M-nadi: the Mahanadi R. Av.: Average, } & \multicolumn{3}{|c|}{ Distrib: Distributaries } & \\
\hline
\end{tabular}


Table 4. The local catchment area Doab wise decanting the runoff to the Chilika lagoon [58]

\begin{tabular}{|c|c|c|c|c|c|c|c|}
\hline sl no & Name of river/major drainages & Length (km) & Catchment area $\left(\mathrm{km}^{2}\right)$ & sl no & Name of river/ drains & Length (km) & Catchment(km²) \\
\hline \multicolumn{4}{|c|}{ South Mahanadi delta system } & \multicolumn{4}{|c|}{ West of Daya-salia doab (continued } \\
\hline 1 & Daya and Rajua & 60 & 540 & 10 & Patnakula & & 4.03 \\
\hline 2 & Nuna drainage sys. & 26 & 445 & 12 & Kantabania & & 6.28 \\
\hline 3 & Bhargovi drainage sys. & 85.5 & 646 & 13 & Chhamankantalbari & & 144.19 \\
\hline \multirow[t]{2}{*}{4} & Ratnachira drainage sys. & 22 & 145.4 & 14 & Badanai & & 86.91 \\
\hline & Total drainage to Chilika from $S M$ & & 1777 & 15 & Batanadi & & 26.19 \\
\hline \multicolumn{4}{|c|}{ West of Daya doab (extension of SMD) Doab XV } & 16 & Kansarinallah & 23 & 160.99 \\
\hline 1 & Gangua sys. (join Daya) & 37 & 740.75 & & sub-total & & 481.57 \\
\hline \multirow[t]{2}{*}{2} & Malaguni sys (join Daya) & 22.5 & 289.01 & \multicolumn{3}{|c|}{ Salia-Rushikulya doab (Doab XVI) } & \\
\hline & total & & 1029.76 & 17 & Salia (River) & 36 & 454.82 \\
\hline \multicolumn{3}{|c|}{ West of Daya-Salia doab (Doab XV) } & & 18 & Janjira d/c & & 8.4 \\
\hline 3 & Kusumi & 8.2 & 141.19 & 19 & Badasankha, Kalajhar d/c & 15 & 128.45 \\
\hline 4 & Saharajodi & 10.5 & 13.5 & 20 & Badaghati $d / c$ & 11 & 179.53 \\
\hline 5 & Weikhia & 16 & 14.05 & 21 & Sabulia drain (Manipalli) & 10 & 88.66 \\
\hline 6 & Tarimi & 7.8 & 86.56 & & sub total & & 859.86 \\
\hline 7 & Makara (Rivulet) & 13 & 159.49 & & Total western catchment & & 2799.78 \\
\hline 8 & Mangalajodi & 6.9 & 62.18 & & Chilika own catchment & & 1560 \\
\hline 9 & Tengulipada & 6 & 4.6 & & & & \\
\hline
\end{tabular}



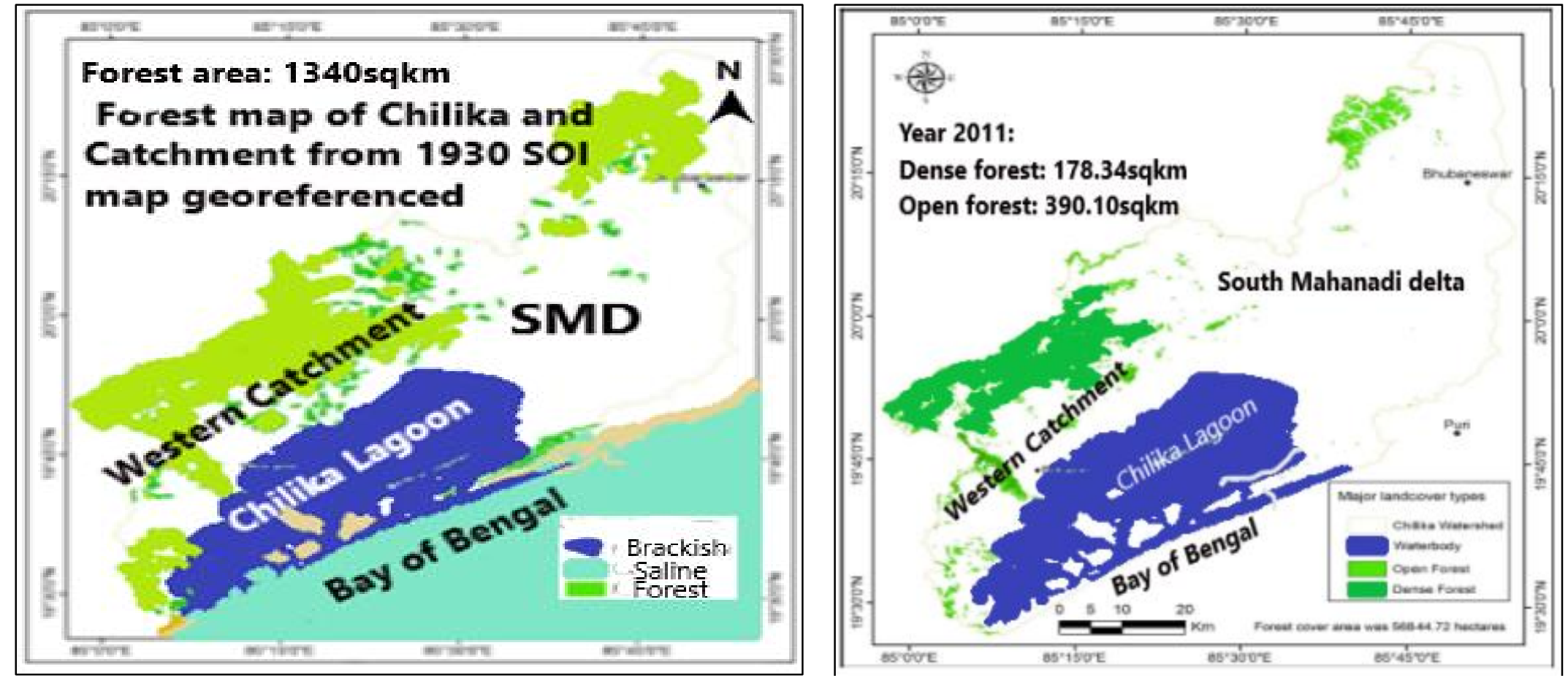

Fig. 4(A). Forests in Chilika catchment (1930), Fig. 4(B). Forests in Chilika catchment area (2011) after geo-referencing (Source: Texas Library) and source modified; http://hdl.handle.net/10603/292449 


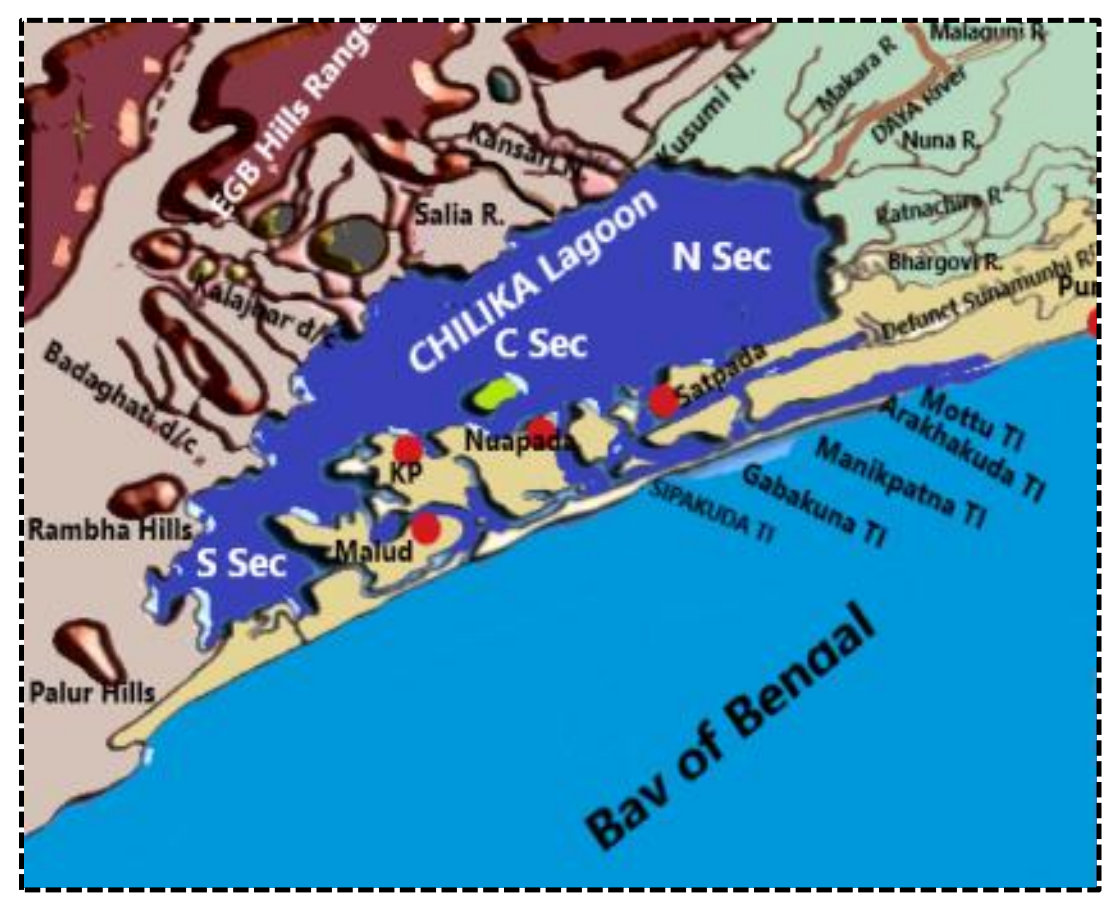

Fig. 5 (a). The 3-D view of the Chilika local catchment (Source modified: http://hdl.handle.net/10603/165773)

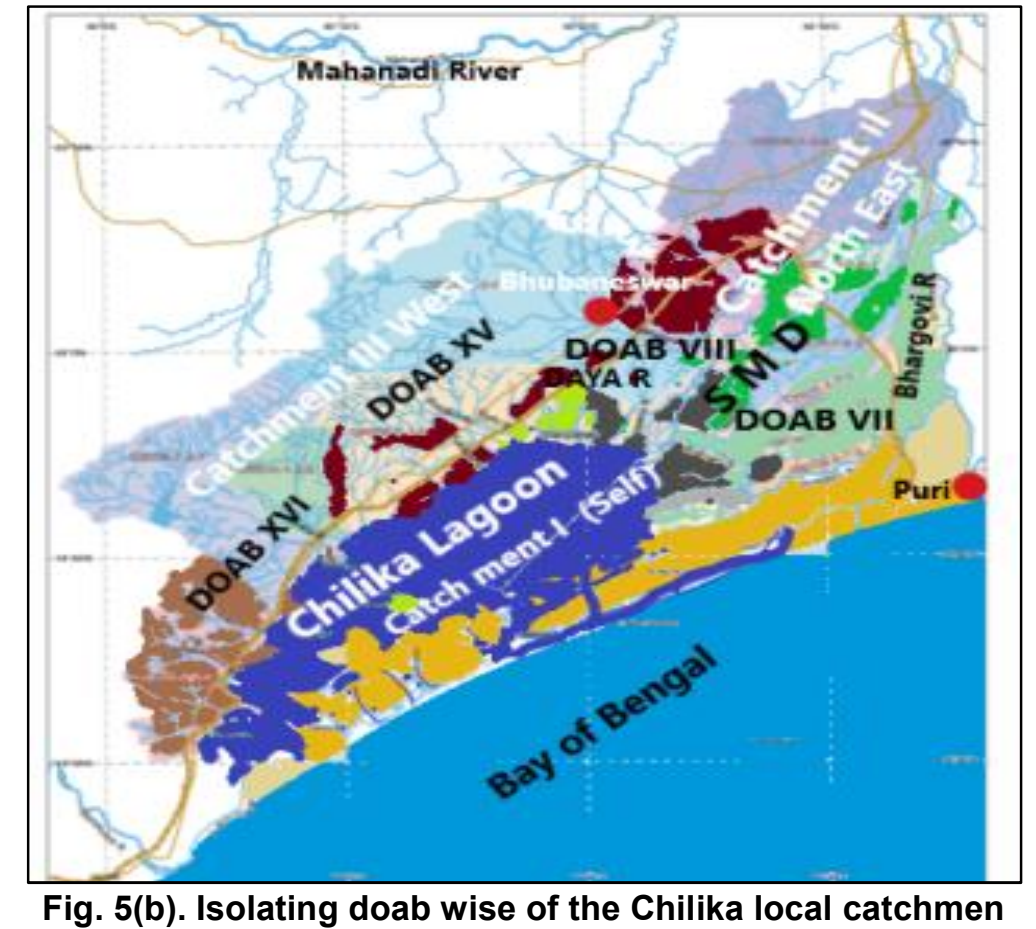




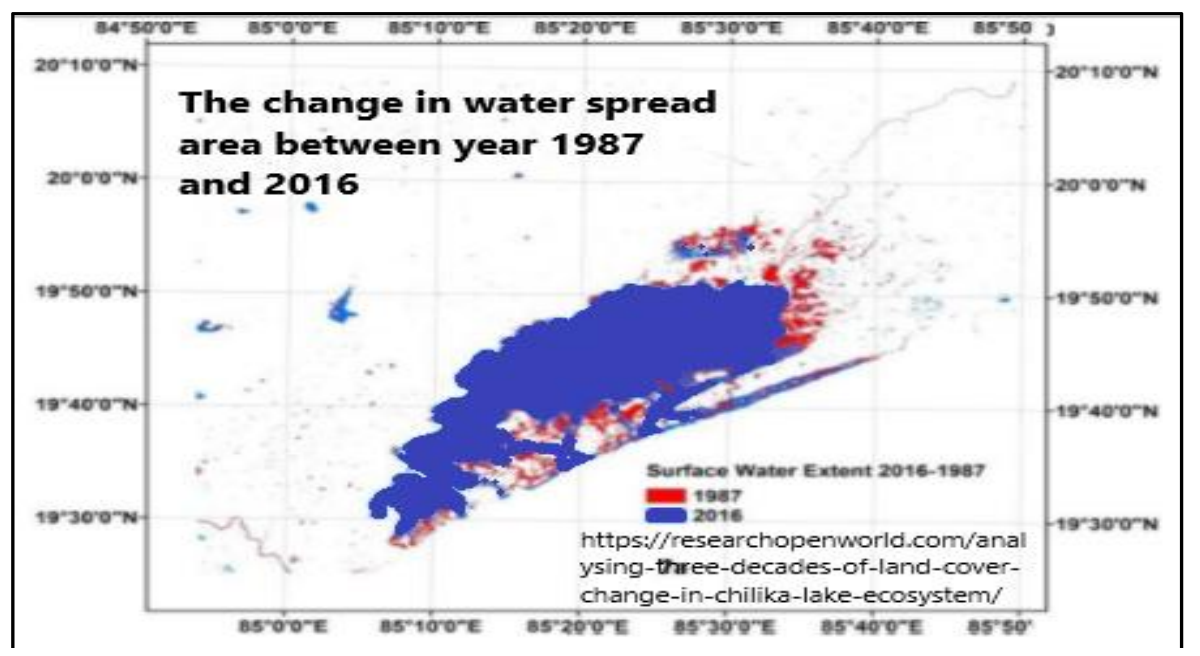

Fig. 6. The Change in water spread area of Chilika between 1987 and 2016 (Red)

\subsection{Barrier Islands and Isles}

The formation of islands and isles are due to inlet shifting, sediment availability, flood bypassing and tidal fluctuations under the hydraulically inefficient outlet channel. There is leftward migration of swash bars or mouth bars and towards the bank, due to unsymmetrical flow, and low wave energy condition in the $\mathrm{OC}$ of Chilika. . They try to join the shoreline due to down-drift or up-drift. Shoals moving towards the barrier face, encounter more tides, with a little time gap between inland waves and tidal current under less sediment movement to form small shoals. The continuous process of transformations of flood deltas and ebb deltas in outer channel and swash zone control flow exchange, northerly movement, closure and opening of tidal inlets. The Chilika lagoon has varying number of Islands due to the making and breaking of Isles within the outer channel. Presently there are 204 numbers of islands comprising of area $223 \mathrm{Km}^{2}$ [54]. The permanent islands with permanent settlements are Parikud, Malud, Nuapada, Garh Krushna Prasad, Kalijai, etc.. The Nalabana (Reed Forest) of about 1553ha is a swamp and a bird sanctuary within the central sector. Few islands are rocky beds in the southern fringe whereas the northern sector has least islands except many isles in the outer channel.

\subsection{Tidal Inlets}

The barrier islands of the Chilika coast are about $34 \mathrm{~km}$ (half) stable and rest narrow unstable spit with an outer channel $(14 \mathrm{Km})$ accommodating the narrow, fragile, dynamic tidal inlets. The Tls are path for transporation of inland and oceanic flow. The dimensions and positioning of the tidal inlets determine the geomorphologic character of the Chilika. Opening of natural tidal inlets by the raising waves of bay disturbances are mostly triggered during full solar eclipse and closing under inland drought and flow paucity Chandramohan et al. [93], Mishra SP. [43]. Unwarranted manual opening of inlet (done 1828 and 2000) had threatened the stake holders in the vicinity of the lagoon under altered geomorphology and hydrodynamics.

The shifts of the tidal inlets are continuous and northerly. The southern fringes of the TI go through accretion and the northern face undergoes erosion. The bi-way motion occur due to shoreline progression/recession east-west. The natural shift is @ of $4.60 \mathrm{~km}$ has occurred between Sept 2000 to 2019 with average rate of northerly shift of $\mathrm{Tl}$ is $242 \mathrm{~m} / \mathrm{year}$.

Historical records reveal the first anthropogenic intervention to the natural $\mathrm{Tl}$ of $1.6 \mathrm{~km}$ wide was hydraulically found inefficient in 1780 and was depleting. Gradually the TI was obstructed thoroughfare of the country boats. During 1825 the shallow $\mathrm{TI}$ was dredged by the Zamindary which was later choked by 1837 . The natural tidal inlets hover in and around Arakhakuda at the debouching point of the Dahikhia river, the second channel after Magarmunha connecting the lagoon and the bay of Bengal.

Lagoons are considered temporal coastal landforms. Historical data points to rapid 
shrinking and sinking of the lagoon in area and shallowness, dimension and positioning of the tidal inlets. The inlet in 1970 was narrow and was migrated extreme north to village Motto having width $(15 \mathrm{~m})$ and depth $(1-2 \mathrm{~m})$ with similar mouth positioning even during 1989. Three or more Tl's were reported during 1933, 1975, 2012 and 2019 either due to number of BoB storms land falling south Odisha coast or/with eclipses with rising tides along the coast [43].

\subsection{Foreshore Landforms}

The foreshore zone (between high tide level and low tide level) is influenced by tidal inlets, waves, barrier islands, tides, mangroves and wind of various $t$ landforms. The physiography's are the beaches, tidal landforms (flats or mudflats or back swamps), coastal sand-dunes, beach ridges, emerging Islands, Isles, mangroves.

\subsubsection{The well-developed beach}

Stable sandy beach has been developed from south of the Chilika (Prayagi) to Sipakuda. with well-built sand dunes and barrier spits running parallel to the coast. The northerly $32 \mathrm{~km}$ of the lagoon has coast has perpendicular sand dunes mainly constructed of river, littoral sediments of recent origin ( 4 to 5 hundred years BP). Beaches are constructed during calm sea with riverine inputs like fine/coarse sands, shingles/ pebbles. Behind the present beach ( $3 \mathrm{~km}$ inland) anther beach profile exists from Satapada to Kushbhadra river mouth.

\subsubsection{Beach vegetation}

The shoreline vegetation has diversified from fresh water plants (Northern Sector), to marine flora along the beach line and behaves as an ecotone which depends up the substratum, chemistry of GW, submergence and emergence period, and the topographic and other edaphic factors. The other coastal areas of the lagoon are amalgamation of fresh, brackish and saline water vegetation. The beach is largely influenced by sand dune vegetation, and the lagoon's breast water has luxuriant growth of brackish water flora.

\subsubsection{Back-shore landforms in SMD}

The impact of oceanic environment continues is prominent along the coastal areas and gradually influenced by one to 20kilimeter inland. They contain swamps, lagoons, lakes, sand dunes, beach ridges, swale deposits, estuaries and other land forms. Apart from the Chilika, there are lakes along the coast like Sar along the Kushabhadra river, Samanga along the coasts of Bhargovi river which has been defunct and converted to swamps, agricultural land or settlements. Bordering the $\mathrm{N}$ - sector, mudflats indicate about the extensions as greater Chilika of past.

\subsubsection{The stable coast}

Aeolian beach sand dunes of length $200 \mathrm{~m}$ to $5 \mathrm{~km}$ and of height 2 to $5 \mathrm{~m}$ (even higher) are commonly found along the SMD and Chilika coast from Prayagi to Ramachandi temple.

The geo hydrological multiple triple points from southern edge propagating from Parikud to Jahnikuda can predict the age of conversion from gulf to a lagoon is also narrated. Along certain stretches of the coasts have large and permanent offshore bars. Towards southern fringe of the coast line (Fig 8).

\subsubsection{Longshore sediment transport}

Odisha has $480 \mathrm{Km}$ coast line out of which $57 \%$ sandy, 33\% muddy, 10\% marshy and have least rock coast line of water depth $10 \mathrm{~m}-15 \mathrm{~m}$ in the offshore region and longshore sediment transport @ 997594m3/year V Sanil ku. et al. [94]. The east coast of India is vulnerable to rise in MSL @ $0.76 \mathrm{~mm} /$ year (Visakhapatnam) and shall submerge the coast line due to large storms striking the coast and flat continental slope Shetye et al. [95].

There is drift of sediment along the offshore is along northerly direction most of the time in the year. The littoral drift is maximum @ $19 \times 104 \mathrm{~m}^{3} / \mathrm{month}$ with velocity $0.8 \mathrm{~m} / \mathrm{s}$ during months of May and June. It is minimum @0.6x104 m/Dec-Jan months. The minimum current $0.4 \mathrm{~m} / \mathrm{s}$ in March, April, July, Sept and $0.3 \mathrm{~m} / \mathrm{s}$ during other months. The sediments received through the inland river move northerly due to wave refraction, the angle of strike, spinning of earth and Coriolis force. The maximum sediment through littoral drift entering via tidal inlets to the lagoon was about $1 \mathrm{MMT}$ annually [96].

The littoral drift along off the Chilika coast cause changes in shore line regularly. The shore line change of the lagoon is analyzed for $64.3 \mathrm{~km}$ from 1975 to 2015. The results obtained were 
accretion due to littoral drift was $62 \%$, and $25 \%$ stable coast. The only length eroded was $13 \%$ of the coast. The rate of accretion and erosion was $9.12 \mathrm{~m}$ and $10.7 \mathrm{~m}$ per annum./ Erosion was in the left fringe and accretion with stability of the spit. was in the right fringe [97].

\subsection{Coastal Plain}

The plain areas back to the shore (SMD) are coastal plain comprising of the tidal or mud flats etc running with agriculture and plantations. The coastal plain along SMD extends up to Jatani areas with scattered agriculture, water logged areas, upland settlements. Beach ridges and tidal land forms have been identified near Jatni and Kanas areas indicate the land was a part to the lagoon in past during its formation stage. These sub-parallel beach ridges and berms comprise of of sand, pebble, shells of varying dimension. No tidal flat / mud flats have been identified in the study area which indicates the sandy beach has been developed under full score.

\subsubsection{The limnology and lithology}

The rivers Daya, and the Bhargovi the third order distributaries of the Mahanadi system debouch the lagoon to $\mathrm{N}$-Sector. Many small serpentine streams emerging from EGB Hills are joining the lagoon from west coast. The hills surrounding the lagoon are composed of hard stratum of metamorphosed Precambrian origin rocks of different genesis like, quartzite, and Chamockites etc that projects as promontories in to Chilika that act as spurs to arrest inflow sediments. The spit is plunged into the Palur Hills along the coastline near. The barrier spit is the a chain of sand dunes connected, [45].

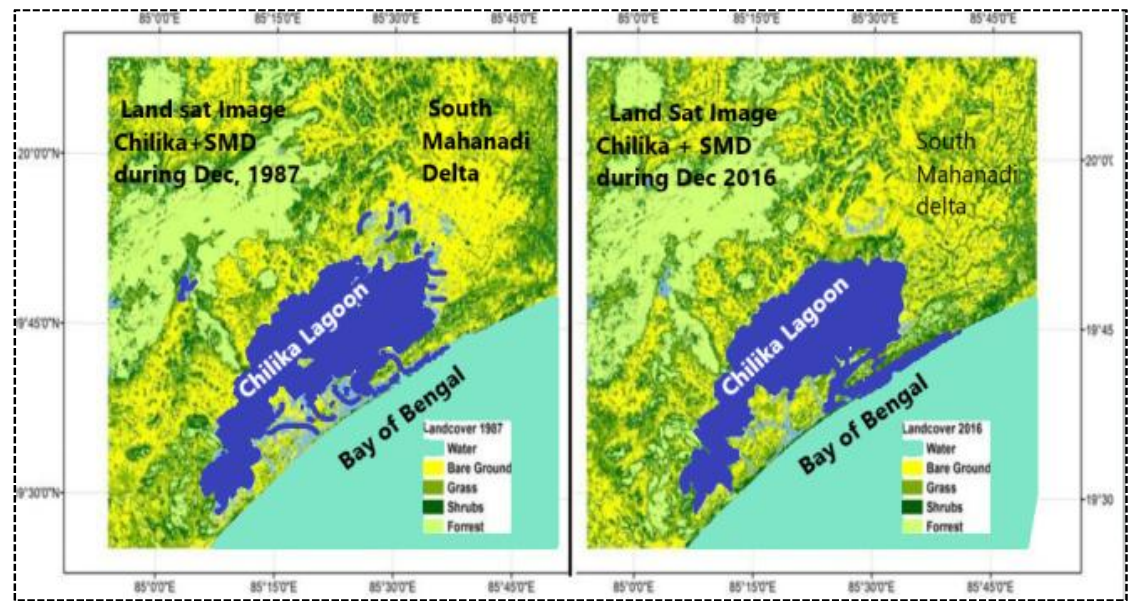

Fig. 7. The contrast of LU/LC in the Chilika and the south Mahanadi delta 1987 and 2016

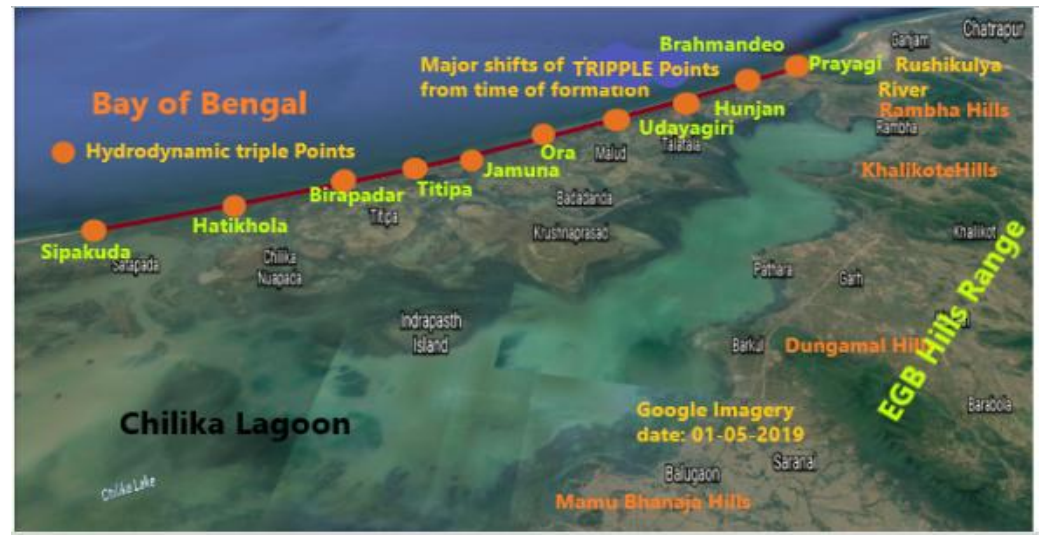

Fig. 8. The regular shift of triple points along coast showing the temporal character of the lagoon 
Table 5. The demography and rough geomorphology status of the Chilika and its catchment

\begin{tabular}{|c|c|c|c|c|c|c|c|c|}
\hline \# & Changes & 1930 & 1972 & 1987 & 1990 & 1999 & 2012 & 2016 \\
\hline & & & Ojha et al. 2013 & Present study & $\begin{array}{l}\text { Wet land Int. } \\
2012\end{array}$ & & $\begin{array}{l}\text { Wet land } \\
\text { Int.2012 }\end{array}$ & Present study \\
\hline 1 & Population density(Puri) & & $286.88(1971)$ & & 428 (1991) & $431(2001)$ & $488(2011)$ & $488(2011)$ \\
\hline 2 & Settlement area (rural + urban) & & $210.09 \mathrm{Km} 2$ & & $204.78 \mathrm{Km} 2$ & & $292.63 \mathrm{Km} 2$ & \\
\hline 3 & Forest all types $\left(\mathrm{Km}^{2}\right)$ & $1339.9(1930)$ & $1340.4(1975)$ & $1070 \mathrm{Km}^{2}$ & $1099.5(1990)$ & $1172.8 \mathrm{Km}^{2}$ & $1346.8 \mathrm{Km}^{2}$ & $1287 \mathrm{Km}^{2}$ \\
\hline 4 & Agriculture $\left(\mathrm{Km}^{2}\right)$ & & 1918.14 & & 2006.9 & 1686.1 & 1257.3 & \\
\hline 4 & Bald terrain/ hills $\left(\mathrm{Km}^{2}\right)$ & & & 1893 & & & & 1743 \\
\hline 5 & Shrub $\left(\mathrm{km}^{2}\right)$ & & 574.58 & 866 & 422.59 & 409.2 & 455.77 & 1046 \\
\hline 6 & Plantation $\left(\mathrm{Km}^{2}\right)$ & & 75.57 & & 99.92 & 45.31 & 34.71 & \\
\hline 7 & Chilika lacustrine area $\left(\mathrm{Km}^{2}\right)$ & 877.37 & 829.84 & & 778.17 & & 699.08 & \\
\hline 8 & Marshes $\left(\mathrm{km}^{2}\right)$ & & 14.72 & & 23.59 & & 15.45 & \\
\hline 8 & Aquaculture $\left(\mathrm{Km}^{2}\right)$ & 00 & 00 & & 11.68 & 17.61 & 51.59 & \\
\hline 9 & Total Water body $\left(\mathrm{km}^{2}\right)$ & & 912.96 & 999 & 918.62 & 910.5 & 887.35 & 860 \\
\hline 10 & Swamps $\left(\mathrm{Km}^{2}\right)$ & & 128.37 & & 121.86 & 116.2 & 97.88 & \\
\hline 11 & Water logged area $\left(\mathrm{Km}^{2}\right)$ & & 58.10 & & 82.60 & 74.85 & 60.31 & \\
\hline
\end{tabular}

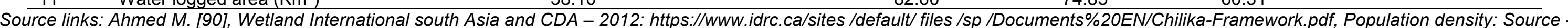

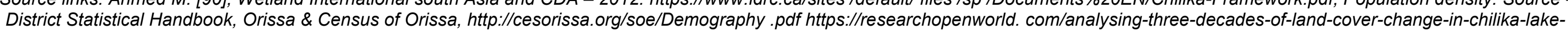
ecosystem/, Ghosh et al. [89] 


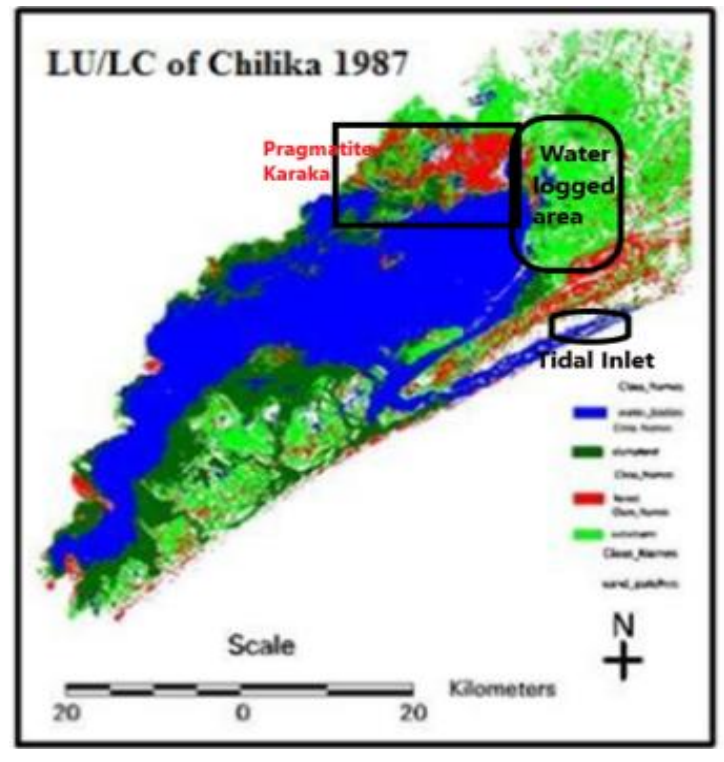

Fig. 9. The LU/LC map of Chilika \& SMD 1987

\subsubsection{The biodiversity}

The Chilika Lagoon act as a spawning/nursery ground numerous marine aqua fauna mostly varying along the channels and central sector. Coastal regulatory zoning is made based on ecological sensitivity as per E 43 A 10 / NE . It starts from CRZ I (the spit; highly eco- sensitive) that includes mangroves, (CRZ IA), the Inter tidal zone (CRZ I B). The CRZ III includes (NDZ area or sand dunes, township, municipalities and corporations as per Annexure-III of CRZ Notification 2011. In around $1100 \mathrm{Km}^{2}$ area of the Chilika lagoon retain many endangered species like linbless lizards (Barakudia insularis), Irrawaddy dolphin, fishing cat (Felis viverrina), white bellied sea eagle (Haliaeetus leucogaster), Platalea leucorodia white spoon bill (Pandion haliaetus osprery) and many other species [98].

\subsubsection{Tourism and biodiversity hub}

Not only Chilika attracted the guest avifauna of cold NW countries even beyond subtropics during winter stay and hatching but also fascinated huge tourist both from foreign and inland to have glimpse of the panoramic view of the lagoon. The record tells a Chilika welcomed tourists were 515381 tourists in 2010, 525637 tourists during 2011,536383 in 2012, 545420 in 2013,555964 in 2014 and 601,666 tourists in 2015 which is continuously rising, Khuntia et al. [99]. The spectacular tidal inlets, the flying birds, dancing dolphins and the bluish fabric of brackish

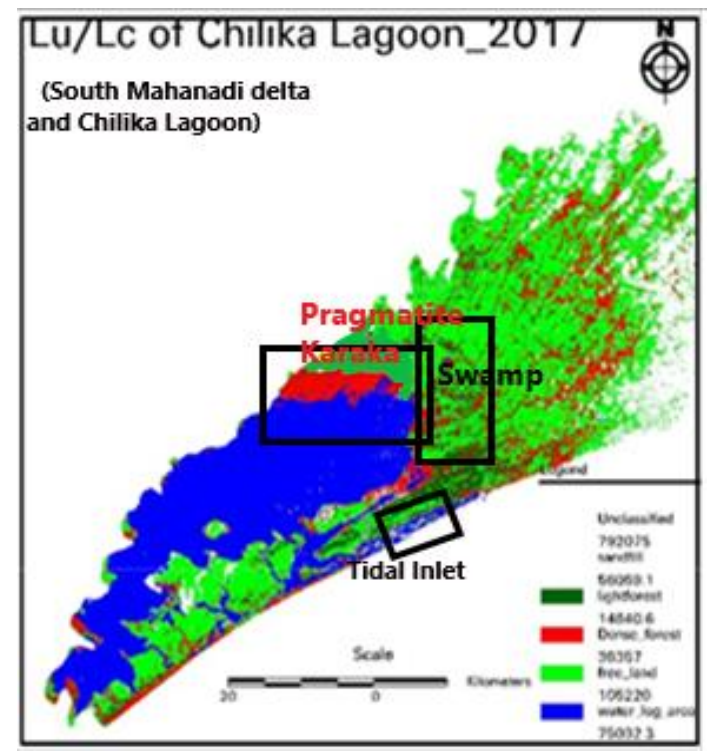

Fig. 10. The LULC map of Chilika and SMD

water attract tourists from inland and foreign to enjoy the panorama of the lagoon.

\subsection{Migratory birds}

Migratory birds visiting Chilika Lake has been improved due to the availability of open spaces for their habitat improvisation after the eviction of illegal prawn gherries by Govt. of Odisha (GoO), and removal of floating phyto-planktons by providing adequate flushing flow by efficient operation of the Naraj barrage by Water Resources Dept. GoO. The arrival of guest birds through central Asian fly from subtropics during winter and the indigenous local birds have increased during the $21^{\text {st }}$ century of 1.142 million of 190species during $5^{\text {th }}$ Jan 2021.It was 0.893 millios (147species) during 2018, 1.048 millions in 2019 , and 1.105 million in the year 2020. The numbers are increasing after the interventions made in the lagoon from 2004.

\section{DISCUSSION}

Present study envisages the elementary morphology, flushing flow, BoB storms, tidal inlets, sediment transport, and dynamic behaviour of the fragile ecosystem of the Lagoon Chilika. Formation of stable, unstable sand spits, islands, terraces, shoals, mudflats, swamps and flood deltas inside the lagoon is discussed. Dimensions of inlet, islet erosion and accretion, barrier island breaching, sediment imbalance, meteorological extremes, and littoral 
drift are controlled by mechanics of sediment transport. Sediment bypassing occur due to wave dynamics near the flood/ebb delta complex, tidal influence and migration of islet complex within the channel [86]. The flood volume is suffering under sediment starvation (reduced by $66.7 \%$ between $1980-2009$ ) as a result there is recession and down drift of the barrier. The geo hydrological multiple triple points from southern edge propagating from Malud to Jahnikuda can predict the age of conversion from gulf to a lagoon is also narrated.

In 3 decades from 1987 to 2017 it is observed that there is prominent decrease in clean water spread, agricultural land, aquatic vegetation, clean water and beach area. It may be due to anthropogenic activities like settlements, building urban infrastructure, prawn gherries and tourism activities etc. However the best management of the lagoon and its basin has developed dense forest and decrease in phytoplankton's, seagrasses and floating weeds etc. The results from the land use and land cover of the Chilika and SMD between the years 1987 and 2017 are in Table 6.

\subsection{Rapid Urbanization in Catchment Area}

During post Holocene (1901-1941) there were only on urban settlement in the catchment of the lagoon i.e the Puri Town. During preAnthropocene (1951-1971), with shifting of the capital of Odisha from Cuttack to Bhubaneswar, the number of urban areas have increased to five with growth rate of $378.98 \%$ (Resurgence Period) whereas during the golden spike perod it has increased to 27 in numbers. The increase in ULB's have surged the quantity of wastes, plastics, construction debris, and industrial rejections. The newly formed Bhubaneswar city, Khurdha as district headquarters, Jatni township, loss of forest, loss of latosol cover and green agricultural land in the catchment area of the lagoon in the south Mahanadi delta. Similarly in the western catchment the major ULB's developed are Tangi, Balugaon, Khalikote, and Rambha The people in the 103numbers of Islands (Prominently Parikud, Malud, Krushna Prasad and Nuapada) are polluting the lagoon with their .

\subsubsection{Ecology of Chilika and its catchment; Anthropocene}

The ecological wealth and health of stake holders of the lagoon based on their economic status, fishing arena, fishing gears, temporal/seasonal fishing, and traditional tourism practices. The rights were vested upon different line departments with an aim to achieve the optimum by over exploiting the available means but not in a coordinated manner. Without delimiting the catch, tourists, harvests the lake users had deteriorated the eco-health of the lagoon by prawn farming, using motorized boats, gill and khonda nets, draining urban waste to the drainage channels debouching the lagoon. The Irrawaddy dolphins, Nalaban $\left(15.53 \mathrm{Km}^{2}\right)$, the hatching and nursing ground for aqua fauna and avifauna, Mangalajodi (the land of high rising grasses) needs to be protected from poachers and intruders with provision of sustained ecosystem services. The ecologically drowning Chilika needs adequate.

\subsection{Present Requirement for the Lagoon}

Under all hydraulic ameliorating measures, the continuous attempt is to provide the lagoon intermittent flushing flow to maintain hydrologic regime and the user's clean water for aquatic habitats. The stake holders of the lake must be provided with drinking water, desalinizing aquifer and recharging groundwater in the basin, better fishing gears (zero mesh) and reducing destructive fishing practices to enhance means for rising aqua catch for poverty alleviation without affecting the ecosystem. It is also essential to increase grazing ground for live stocks, planting fast growing mangroves, the watershed and river corridor must be under afforestation, protecting natural habitats from poaching, controlling bird flu for preserving biodiversity. It is essential to abandon the prawn gherries (presently $\approx 13-14 \%$ of total area), fishing right for the natives along with fishing regulation during breeding periods, charging zero waste to lagoon, fixing navigation route, abandoning fishing during hatching time, restricting fishing in the $\mathrm{OC}$, legalising fishing zone and finally utilizing the phytoplankton and sea grasses for human use. Actions must be taken to protect the lake users for a peaceful settlement the restoration of cultural activities, recreational and aesthetic values, http://www.chilika.com/ documents/ publication_ 1564535640.pdf.

The fast urbanization and modern agricultural drives have left imprints on the geo-bio-hydro environment of the area since Anthropocene. Land use and land cover analysis divulges that the canopy of the area and basin's forest 
Table 6. The comparative study of the geomorphology of the lagoon Chilika from 1987 to 2017

\begin{tabular}{llllll}
\hline Name & $\begin{array}{l}\text { Area (ha) } \\
\mathbf{1 9 8 7}\end{array}$ & $\begin{array}{l}\text { Area (\%) of } \\
\mathbf{1 9 8 7}\end{array}$ & $\begin{array}{l}\text { Area (ha) } \\
\mathbf{2 0 1 7}\end{array}$ & $\begin{array}{l}\text { Area (\%) } \\
\mathbf{( 2 0 1 7 )}\end{array}$ & $\begin{array}{l}\text { Increase in } \\
\text { \% }\end{array}$ \\
\hline Muddy Water & 6882.5 & 1.92 & 2079.99 & 0.58 & Reduced \\
Beach & 729.27 & 0.22 & 625.59 & 0.17 & Decreased \\
Clean Water & 97179.5 & 27.23 & 94118.1 & 26.36 & Decreased \\
Dense Forest & 22680.1 & 6.35 & 29307.9 & 8.21 & Increased \\
Mixed Vegetation & 57562.6 & 16.12 & 84615.8 & 23.70 & Increased \\
Aquatic Vegetation & 36246.8 & 10.16 & 32846.8 & 9.20 & Decreased \\
Agricultural Land & 97595.4 & 27.35 & 70627.7 & 19.78 & Decreased \\
others & 38024.5 & 10.65 & 42721.7 & 11.96 & Increased \\
\hline
\end{tabular}

expanse have been shrank by $53 \mathrm{Km}^{2}$ from 1987 to 2017 in spite of arduous actions for the forest survival. The delta has lost 4600 hectares of agriculture land and 360 hectares of pristine mangrove forest to urban/rural settlements and aquaculture2001 and 2011 alone.

The delta is shrinking and sinking which has created challenging threat. The vulnerable communities are the fisher folk and the stake holders are the worst sufferers. In addition natural calamities like storms 1971, 1981, 1998, 2013, 2014, and 2019 have changed the configuration of the lagoon's morphology and landform [100]. There is asymmetric flow distribution in the main Mahanadi and the Kathajodi branch. The asymmetric percentage of flood flow also changes is caused after each very high flood (>40000cusec) causing potential devastations to the delta and the lagoon users.

\section{CONCLUSION}

To save the lagoon from ecological and hydrological degradation; it is essential for the south Mahanadi delta to have both soft and hard measures with effective operation of the Naraj barrage. The catchment treatment plan is to be encouraged against entry of inland sediment to the lagoon, control of weeds, sea grass, ipomeas, and water hyacinth, maintaining the tidal inlets to for salinity, augmenting conducive atmosphere for growth of aqua fauna and tempt more migratory birds to cluster within the lagoon. The prohibition of waste influx through the inflowing drainage channels and invoking the flushing flow by regulating barrage through planned operation procedures, catchment treatment plan, luring ecotourism, socio economic development of stake holders and lake users, destroying prawn culture farms etc.. Introduction of solar panels for boat operation, use of bio degradable plastics, plantation of mangroves, training the fishermen for their capacity building against poaching, organic farming in the out skirt and within the lake islands is essential.

The present protocol for the lagoon should be safety of waterfowl, other faunal species and the indigenous flora by catchment treatment, restricting weed infestation, pollution control, public awareness and community participation among the stake holders, capacity building, controlled fishing and encouraging clean energy technology for transportation along with intensive research and development for a sustained biodiversity.

\section{COMPETING INTERESTS}

Authors have declared that no competing interests exist.

\section{REFERENCES}

1. Kjerfve B. Coastal lagoons, Coastal lagoon processes. Editor Bjorn Kjerfve, Elsevier oceanography series. Elsevier science publishers B.V. 1994; 60:1-576

2. Khandelwal $A$, Mohanty $M$, Rodriguez $F$. G, Scharf WS. Vegetation history and sea level variation during the last 13,500 years inferred from a pollen record at Chilika Lake, Orissa, India. Vegthist Archaeobot, Springer verlag-07. 2008;17:335-344

3. Crutzen P, Stoermer E, The Anthropocene. IGBP Newsletter, 2000;41:17-18.

4. Zalasiewicz Jan, Williams $M$, Haywood $A$, Ellis M. The Anthropocene: A New Epoch of Geological Time? Philosophical Transactions of the Royal Society 2011; 835-841.

5. Mishra SP, Human Evolution and Extermination up to Present Anthropocene: India. Journal of Shanghai Jiaotong University; JSJ. 2020;16 (7):115-133.

ISSN: 1007-1172. 
6. Sterling, Andrew, Orissa, its geography, statistics, history, religion and antiquities. John Snow, 35 Paternoster Row, sold by Brooks, Leicester, Noble, Boston 1846. Source: British library; 1846.

7. Cotton AT. General, report on the Mahanadi River, source. Water Resources Dept. Library Odisha. 1858;8.

8. Harrish JC, Young CB. Reports and correspondence relative to the control of the mahanadi river at Cuttack, correspondences between the Chief engineer and superintending Engineer and Executive engineer, lower provinces 1858 to 1860 , source Water Resources Dept. Library Odisha; 1860.

9. Blandford WT. Note on the laterite of Orissa. T. Oldham, (editor) Memoirs of the Geological Survey of India. 1859;1:253276.

10. Mahalanobis PC. Mahalanobis Reports, Source: Irrigation and power dept., Orissa; 1940.

11. Hunter WW. Orissa or the vicissitudes of an Indian Province under Native and British Rule. Vol- II, London, 1872;182,

12. Sewell RBS. Hydrography of the Rambha Bay. Mem. Indian Mus. 1922;3(10):679690.

13. Williams, et al, Svarup, Bishnu. Orissa Flood committee report-1928", Irrign'. Dept., Govt. of Bihar and Orissa; 1928.

14. Biswas K. algal flora of the Chilika Lake. Memoirs of the Asiatic Society of Bengal. Royal Asiatic Society of Bengal. Calcutta. 1932;11(5):165-198.

15. Stephenson J. Littoral oligochaeta from the Chilka Lake on the east coast of India, Rec. Indian Mus. 1914;10: 225-262.

16. Annandale N. Fauna of the Chilka Lake: Mammals, Reptiles and Batrachiana. Mem. Indian Mus., 19155(2): 163-174.

17. Annandale, N. and S. Kemp (1915). Fauna of the Chilka Lake. Sponges. Mem. Indian Mus, 5(1): 21-54.

18. Chaudhuri, B. L. (1916). Fauna of the Chilika Lake: Fish, Part I. to part IV); Mem.Indian Mus., 5(4, 5, 6, 11): 403-439. 441-458., 491-508, 711-736.

19. Chilton C. Fauna of Chilika, 1916, Zoological Survey of India. 1916;5(5). 459-482.

20. Mitra GN. The development of the Chilika lake. Orissa Government Press, Cuttack. 1946;1-26.
21. Pritchard DW. Salinity distribution and circulation in the Chesapeake Bay estuarine system. J Mar Res. 1952;11: 106-123.

22. O'Brien MP Estuary and tidal prisms related to entrance area. Civil Engineering. 1931;1(8):738-739.

23. Phleger FB. Some general features of coastal lagoons. In: Ayala-Castaneres A (ed) Lagunas Costeras. Universidad Nacional Autonoma de Mexico, Mexico, DF. 1969;5-26

24. Kjerfve B, Magill K. Geographic and hydrographic characteristics of shallow coastal lagoons. Mar Geol. 1989;88:187199.

25. Kjerfve B. Coastal lagoons. In: Kjerfve B (ed) Coastal lagoon processes. Elsevier, Amsterdam. 1994;1-8.

26. Lankford RR. Coastal lagoons of Mexico: their origin and classification. In: M. Wiley, Ed. Estuarine Proceses. Academic Press, New York, NY, USA. 1976;2:192-216

27. Fairbridge RW. The estuary: Its definition and geodynamic cycle. In: E. Olavsson and I. Cato, Eds. Chemistry and Geochemistry of Estuaries. John Wiley \& Sons, New York, NY, USA. 1980;1-35

28. Fitz Gerald DM, Georgiou I, Miner M, Masselink G, Gehrels R. Estuaries and tidal inlets. In: Coastal environments and Global change, Wiley. 2013;268-298.

29. Mishra SP, Jena JG. Migration of tidal inlets of Chilika Lagoon, Odisha, India -A Critical Study. Int Journal of Engineering and Technology. 2014;6:2453-2464.

30. Mishra SP. Rejuvenation of lagoons along the east coast of India, management: Anthropocene approach. Int Jr of Adv. Research. 2019;7(1):688-714. DOI:URL:http://dx.doi.org/10.21474/IJAR0 1/8378

31. Mee LD. Coastal lagoons. In: Riley JP, Chester R (eds. Chemical oceanography 7. Academic Press, New York. 1978;441490.

32. Mangor K, Brøker I, Rand P, Hasløv D, Waterfront developments in harmony with nature. In book: Coastal and Ocean Engineering Practices. 2012;1-30.

33. Nayak PK. The chilika lagoon socialecological system: An historical analysis. Ecology and Society. 2014;19(1):1. DOI: http://dx.doi.org/10.5751/ES-05978190101 
34. Pradhan S, Mishra SK, Baral R, Samal RN, Mohanty PK. alongshore sediment transport near tidal inlets of Chilika Lagoon; East Coast of India, Marine Geodesy. 2017;40:2-3,187-203,

DOI: $10.1080 / 01490419.2017 .1299059$

35. Biswas KP. Ecological and fisheries development in wetlands -A case study of Chilika lagoon. Daya Publishing House, Delhi. 1995;110035:189.

36. Dasgupta S, Fukuoka M, Roy S. Hematitepyrophanite intergrowth in gondites, Chilka area, Sausar Group, India. Mineralogical Magazine. 1984;48:558-560.

37. Tripathy SK. Hydrological studies in Chilika Lake, a tropical lagoon. M. Phil. Dissertation, Berhampur University, Orissa; 1985.

38. Samal RC. Remote sensing on geomorphic and sedimentologic evolution of the coastal tract between Dhamara and Paluri, Orissa, India. Ph. D. Thesis; Utkal Univ.,Bhubaneswar. 1993;198.

39. Government of Orissa, Delta Development plan, Stage II. Water resources Dept. (unpublished); 1985.

40. Anand NM, Chandramohan P. Studies on waves and longshore sediment transport along the coastline of Chilika Lake, NIO, Goa. 1992;1-4.

41. Mishra SP. Management of the sediment transported by the south Mahanadi deltaic rivers to the Chilika lagoon. Int Jour Adv Research. 2017;5(6):1005-1020.

42. Bhattacharya S, Sen SK, Acharyya A. Structural evidence supporting a remnant origin of patchy charnockites in the Chilka Lake area, India. Geol Mag. 1993;130: 363-368.

43. Bhattacharya S, Sen SK, Acharyya A. The structural setting of the Chilika Lake granulite- migmatite-anorthosite suite with emphasis on the time relation of charnockites. Precamb. Res. 1994;66(1-4): 393-409.

44. Sarkar SK, Bhattacharya A., Bhattacharya AK, Satpathy KK, Mohanty AK, Panigrahi S. Chilika Lake. In: Bengtsson L., Herschy R.W., Fairbridge R.W. (eds). Encyclopedia of lakes and reservoirs. Encyclopedia of Earth Sciences Series. Springer, Dordrecht; 2012.

DOI: https://doi.org/10.1007/978-1-40204410-6_57

45. Venkataratnam K. Formation of the barrier spit and other sand ridges near Chilika
Lake on the east coast of India. Marine Geology. 1970;9(2):101-116.

46. Mohapatra LK. Fishing \& Fishermen on the Chilika Lake in Orissa. India. Museum Bulletin. 1973;8(1).

47. Kachar KS. Chilika Lake. A pilot survey of birding possibilities, J Bomb Nat Hist Soc. 1966;63(2):290-297.

48. Jhingran VG. Report on the fisheries of the Chilka lake 1957-1960, Bulletin, CIFRI. 1963;1:113.

49. Venkataratnam K. Studies on some aspects of the sediments of Chilika Lake. Ph.D. thesis, Department of Geology, Andhra University, India. 1965;268.

50. Roychaudhuri B. The fishing communities of Chilika: A study in their ecosystem. Journal of the Indian Anthropological Society. 1977;12(2):101-112.

51. Banerjee AC. Hydrology of Chilika Lake. In: Summer Institute on brackish water capture and culture Fisheries. Central Inland Fisheries Research Institute (ICAR), Barrackpore, West Bengal. 1980;1-8.

52. Bhattacharya S. Review: The charnockite problem, a twenty first century perspective. Natural Science. 2010;2(1):402-408.

53. Sahu BK, Pati $P$, Panigrahy RC. Environmental conditions of Chilika lake during pre and post hydrological intervention: an overview, Springer. Journal Coast Conservation. 2014;18:285297.

54. Nandy Ku A. Geology of Chilika Lake; 2016.

Available:https:// aknandy. wordpress.com /2016/ 12/14 /geology-of-chilika-lake/

55. Das Bishnu $P$, Jena J. Impact of mahanadi basin development on eco-hydrology of Chilika. In: Sengupta, M. and Dalwani, R. (eds.) Proceedings of Taal 2007: The 12th World Lake Conf. 2008;697-702.

56. Das Lalu, Jitendra Kumar Meher, Monami Dutta. Construction of rainfall change scenarios over the Chilka Lagoon in India.Atmospheric Research. 2016;182: 36-45.

57. Mukherjee Subham. Influence of discharge of river Daya in Chilika Lagoon: A brief study using mohid simulation model. Suresh Gyan Vihar University. Journal of Engineering \& Technology (An International Bi-Annual Journal). 2016;2 (2):10-21.

58. Mishra SP, Jena JG. Geophysical changes of Chilika lagoon in post Naraj barrage 
period; PhD thesis, 2016,Sikhya o' Anusandhan Univ. Inflibnet; 2016.

Available:http://hdl.handle.net/10603/ 136580

59. Mishra SP, Jena JG. Intervention of Naraj Barrage: Its effects on sediment inflows into Chilika Lake, India. Lakes and Reservoirs: Research and Management, Wiley Blackwell, John Wiley and sons, Australia. 2015;20:77-88

60. Hazra S, Das S, Ghosh A, Raju PV, Patel A. The mahanadi delta: $A$ rapidly developing delta in India. In: Nicholls R., Adger W., Hutton C., Hanson S. (eds) Deltas in the Anthropocene. Palgrave Macmillan, Cham; 2020.

Available:https://doi.org/10.1007/978-3030-23517-8_3

61. Mahanty MM, Mohanty P, Patnaik Ku A, Samal RN, et al. Hydrodynamics, temperature/ salinity variability and residence time in the Chilika lagoon during dry and wet period: Measurement and modeling Cont Shelf Research. 2016;125:28-43.

DOI: 10.1016/j.csr.2016.06.017

62. Pattanaik S. Conservation of environment and protection of marginalized fishing communities of Lake Chilika in Orissa, India. J Hum Ecol. JHE 1507, (c) KamlaRaj; 2001.

63. Bhatta KS, Pattnaik AK. Environmental monitoring of Chilika lake Proc. Inter. Workshop on sustainable Development of Chilika lake. Orissa, Bhubaneswar. 2002; 95-113.

64. Mishra SP, Jena JG. Morphological reconstruction of Southern Mahanadi Delta and Chilika Lagoon, India - a critical study. Int. Journal of Advanced Research. 2015;3(5):691-702.

65. Mishra SP, Sethi Ku B, Barik Ku K. Delta partitioning, geospatial changes, anastomosis of Mahanadi Tri-delta, India. International Journal of Earth Sc and Eng Caffetinnova org. 2019;12(1):21-40.

DOI: 10.21276/ijee.2019.12.0103

66. Panigrahi S, Acharya BC, Panigrahy RC, Nayak BK, Banarjee K, Sarkar SK. Anthropogenic impact on water quality of Chilika lagoon RAMSAR site: A statistical approach. Wetlands Ecology and Management. 2007;15(2):113-126.

67. Parida Saibala, Bhatta KS. Watershed and livelihood through picsi-culture. Souv. 5th
Chilika Mahotsav, Chilika Development Authority, Bhubaneswar. 2017;111-113.

68. Barnes RSK. Costal lagoons. Cambridge studies in Modern Biology. 1980;105.

69. Rao NK, Takayasu K, Sada Kata N, Hema Malini B. Holocene evolution of deltas on the east coast deltas of India, present status and future prospects. Kay R, editor, Deltas of the World, N.Y. Am Society of Civil Eng. 1993;010-015.

70. Gupta GVM, Sarma VVSS, Robin RS. Raman AV, Jai Kumar M, Rakesh, Subramanian BR. Influence of net ecosystem metabolism in transferring riverine organic carbon to atmospheric $\mathrm{CO} 2$, in a tropical coastal lagoon (Chilika Lake, India). Biochemistry. 2008;87:265285.

71. Ghosh AK, Pattnaik AK. Chilika lagoon experience and lessons learned brief. UNEP Int. Waters learning exchange and resource network. 2008;115.

Retrieved: 2008-12-23, 2008.

72. Mukherjee M, Suresh VR, Manna RK. Microplankton dynamics of a coastal lagoon, Chilika: interactive effect of environmental parameters on microplankton groups. Environ Monit Assess. 2018;190:689.

DOI: https://doi.org/10.1007/s10661-0187049-9

73. Raman AV, Satyanarayan C, Adiseshasai K, Prakash KP. Phytoplankton characteristics of Chilika Lake, a brackish water lagoon, east coast of India. Indian J Mar Sci. 1990;19:274-277

74. Chilika Dev. Authority DPR. Integrated Coastal Zone Management: Strengthening of wetland research \&training centre and bio-diversity conservation on Chilika Lagoon. czmpodisha. org/.../Chilika; 2012.

75. Majharul Islam Sk, Paul AK. Geospatial technologies for assessment of the role of chilika lagoon and its present environmental status on the economy occupation and hazard of the coastal society of Khurda Puri and Ganjam districts of Orissa. PhD Thesis, Vidyasagar University; 2016.

Available:http://hdl.handle.net/10603/2924 49

76. Biswas KP. Ecology and fisheries development in wetlands: A study of Chilika lagoon. E-book, Google. 1995;192.

77. Central Inland Capture Fisheries Research Institute (CIFRI), Chilka Lake - Present 
and Past. Bulletin-80, Indian Council of Agricultural Research), Barrackpore-743 101West Bengal. 1998;1-46.

78. Mishra SP. Management of the sediment transported by the south Mahanadi deltaic rivers to the Chilika lagoon. Int Jour Adv Research. 2017;5(6):1005-1020.

79. Ghosh Asish. Experience brief for Chilika lake, Orissa, India. Center for Environment and Development. 2003;22:2003.

80. Mishra SP. Estuaries and lateral channel development along east coast of India, International Journal of Advance Research. 2016;4(12):2360-2371.

81. Pearson W. Chilika Chart, the bathymetry map of Chilika lake, First Officer of $\mathrm{H}$. M. Surveying Brig. Krishna, source Water Resources Dept. Library Odisha (Unpublished); 1858.

82. Kanungo A, Panda GK. Morphology of the coastal landforms Along the Orissa coast A study based on remote sensing. Thesis, Dept. of Geography, 2010;17:140.

Available:http://hdl.handle.net/10603/2813 74

83. Unnikrishnan AS, Rup Kumar K, Fernandes SE. Sea level changes along the Indian coast: observations and projections. Curr Sci. 2006;90;362-368.

84. Naidu AS. Some aspects of texture, mineralogy and geochemistry of modern deltaic sediments of Godavari River. Unpubl. PhD thesis submitted to Andhra University, Waltair, India. 1968; 250.

85. Somanna K, Reddy ST, Rao MS, Geomorphology and evolution of the modern mahanadi Delta using remote sensing data. International Journal of Science and Research (IJSR). 2016; 5(2):1329-1335.

86. Bruun P, Gerritsen F. Natural bypassing of sand at coastal inlets. Jr. of the Waterways and Harbors Division, ASCE. 1959;85:401412

87. Finlayson CM, Rastogi G, Mishra DR, Pattanak AK. Ecology, conservation, and restoration of Chilika Lagoon, India; Springer, Book. 2020;15.

88. Ramesh $\mathrm{R}$, Purvaja $\mathrm{R}$, Lakshmi $\mathrm{A}$, Newton, A, Kremer HH, Weichselgartner J. South Asia Basins: LOICZ global change assessment and synthesis of river catchment - Coastal sea interaction and human dimensions. LOICZ Research \& Studies No. 32. GKSS Research Center, Geesthacht. 2009;121.
89. Ghosh AK, Pattnaik AK, Ballatore TJ. Chilika lagoon: Restoring ecological balance and livelihoods through resalinization. Lakes and Reservoirs: Research and Management. 2006;11:239255

90. Ahmed M. Census of India, Orissa, Part IReport, 1951;11.

Available:http://lsi.gov.in:8081/jspui/bitstre am/123456789/6821/1/7732_1951.pdf

91. Fairbridge RW. Swash, swash mark. In: Geomorphology. Encyclopedia of Earth Science. Springer, Berlin, Heidelberg; 1968.

DOI: https://doi.org/10.1007/3-540-310606_364

92. Mishra SP. Delineation of fluvial-Aeolian dunes along the SMD and Chilika coasts of Odisha, India. Int. Journal of Advance Research. 2017;5(12):412-425.

DOI: 10.21474/IJAR01/5975

93. Chandramohan P, Nayak BU. A study for the improvement of the Chilka Lake Tidal Inlet, East Coast of India. Journal of Coastal Research. 1994;10 (4):909-918.

94. Sanil Kumar V, Pathak KC, Pednekar P, Raju NSN, Gowthaman R. Coastal processes along the Indian coastline, Current Science. 2006;91(4):530-536.

95. Shetye SR, Gouveia AD, Pathak MC. Vulnerability of the Indian coastal region to damage from Sea levek rise, Current Science. 1990;59 (3):152-156.

96. Chandramohan P, Sanil Ku V, Nayak BU. Coastal processes along the shore front of Chilika Lake, East coast of India. Ind J of Marine Science. 1993;22:268-272.

97. Baral R, Pradhan S, Samal RN, et al. Shoreline change analysis at chilika lagoon coast, India using digital shoreline analysis system. J Indian Soc Remote Sens 2018; 46:1637-1644.

DOI: https://doi.org/10.1007/s12524-0180818-7

98. Peetabas N, Panda RP. Conservation and management of bioresources of Chilika Lake, Odisha, India, Int. Jr. of Scientific and Research Pub. 2015;5(7):1-4.

99. Khunti N, Mishra JM. Sustainable tourism development in wetlands a study with reference to Chilika lake Odisha; thesis, Department of Tourism Studies; Pondicherry University. 2017;2. Available:http://hdl.handle.net/10603/2599 06 
100. Mishra SP, Ojha AC. Fani an Outlier among Pre-monsoon Intra-Seasonal Cyclones over Bay of Bengal. International
Journal on Emerging Technologies. 2020; 11(2): 271-282.

ISSN : 2249-3255

(C) 2021 Mishra et al.; This is an Open Access article distributed under the terms of the Creative Commons Attribution License (http://creativecommons.org/licenses/by/4.0), which permits unrestricted use, distribution, and reproduction in any medium, provided the original work is properly cited.

Peer-review history:

The peer review history for this paper can be accessed here:

http://www. sdiarticle4.com/review-history/66525 